\title{
Article \\ Phytochemical Characterization and Evaluation of the Antioxidant and Anti-Enzymatic Activity of Five Common Spices: Focus on Their Essential Oils and Spent Material Extractives
}

\author{
Adriana Trifan ${ }^{1}\left(\mathbb{D}\right.$, Gokhan Zengin ${ }^{2,+}{ }^{-1}$, Mihai Brebu ${ }^{3} \mathbb{D}$, Krystyna Skalicka-Woźniak ${ }^{4, *}$ \\ and Simon Vlad Luca ${ }^{1,5, *}$
}

Citation: Trifan, A.; Zengin, G.; Brebu, M.; Skalicka-Woźniak, K.; Luca, S.V. Phytochemical Characterization and Evaluation of the Antioxidant and Anti-Enzymatic Activity of Five Common Spices: Focus on Their Essential Oils and Spent Material Extractives. Plants 2021, 10, 2692. https://doi.org/ $10.3390 /$ plants10122692

Academic Editors: Corina Danciu and Monika Czerwinska

Received: 6 November 2021

Accepted: 6 December 2021

Published: 7 December 2021

Publisher's Note: MDPI stays neutral with regard to jurisdictional claims in published maps and institutional affiliations.

Copyright: (C) 2021 by the authors. Licensee MDPI, Basel, Switzerland. This article is an open access article distributed under the terms and conditions of the Creative Commons Attribution (CC BY) license (https:/ / creativecommons.org/licenses/by/ $4.0 /)$.
1 Department of Pharmacognosy, Faculty of Pharmacy, "Grigore T. Popa" University of Medicine and Pharmacy Iasi, 700115 Iasi, Romania; adriana.trifan@umfiasi.ro

2 Physiology and Biochemistry Research Laboratory, Department of Biology, Science Faculty, Selcuk University, 42130 Konya, Turkey; gokhanzengin@selcuk.edu.tr

3 Physical Chemistry of Polymers Laboratory, "Petru Poni" Institute of Macromolecular Chemistry, 700481 Iasi, Romania; bmihai@icmpp.ro

4 Department of Natural Products Chemistry, Medical University of Lublin, 20-093 Lublin, Poland

5 Biothermodynamics, TUM School of Life and Food Sciences, Technical University of Munich, 85354 Freising, Germany

* Correspondence: kskalicka@pharmacognosy.pl (K.S.-W.); vlad.luca@tum.de (S.V.L.)

+ Author with equal contribution as the first author.

\begin{abstract}
The essential oil industry of aromatic herbs and spices is currently producing a significant amount of by-products, such as the spent plant materials remaining after steam or hydrodistillation, that are simply discarded. The aim of this study was to comparatively investigate the phytochemical composition, antioxidant and multi-enzymatic inhibitory potential of the essential oils and spent plant material extractives obtained from cinnamon, cumin, clove, laurel, and black pepper. The essential oils were characterized by the presence of several phytochemical markers (cinnamaldehyde, cuminaldehyde, eugenol, eucalyptol, $\alpha$-terpinene, limonene, $\beta$-caryophyllene or $\beta$-pinene). On the other hand, the LC-HRMS/MS profiling of the spent material extracts allowed the annotation of species specific and non-specific metabolites, such as organic acids, phenolic acids, flavonoids, proanthocyanidins, hydrolysable tannins, fatty acids, or piperamides. All samples exhibited very strong antioxidant effects, with the clove essential oil displaying the strongest radical scavenging (525.78 and $936.44 \mathrm{mg} \mathrm{TE} / \mathrm{g}$ in DPPH and ABTS assays), reducing (2848.28 and $1927.98 \mathrm{mg}$ TE/g in CUPRAC and FRAP), and total antioxidant capacity $(68.19 \mathrm{mmol} \mathrm{TE} / \mathrm{g})$. With respect to the antiacetylcholinesterase (0.73-2.95 mg GALAE/g), anti-butyrylcholinesterase (0-3.41 mg GALAE/g), anti-tyrosinase (0-76.86 mg KAE/g), anti-amylase and anti-glucosidase (both 0-1.00 mmol ACAE/g) assays, the spice samples showed a modest activity. Overall, our study reports that, not only the volatile fractions of common spices, but also their spent plant materials remaining after hydrodistillation can be regarded as rich sources of bioactive molecules with antioxidant and multi-enzymatic inhibitory effects.
\end{abstract}

Keywords: antioxidant; anti-enzymatic; spices; aromatic plants; by-products; LC-HRMS/MS

\section{Introduction}

Aromatic herbs and spices have been important components of human nutrition since antiquity and are considered as rich dietary sources of phytochemicals for both flavoring and medicinal applications. Aromatic herbs and spices are commonly used in households as culinary ingredients, but their derived essential oils and extracts found various applications within food, confectionery, perfumery, cosmetics, and pharmaceutical sectors [1]. Besides their distinctive flavor profile, aromatic herbs and spices are highly appreciated 
as natural preservatives in foods due to antioxidant and antimicrobial propensities [2]. Since time immemorial, aromatic herbs and spices have also been employed as traditional remedies in various Asian traditional medicine systems (Chinese, Indian, Korean, and Japanese), which later prompted extensive research concerning their phytoconstituents and potential biological effects [2,3]. Indeed, distinct aroma profiles are attributable to marker compounds such as cinnamaldehyde in cinnamon, eugenol in clove, piperine in black pepper; in addition, various studies showed that these phytochemicals not only give the specific flavor, but also possess significant antimicrobial, antioxidant, anti-inflammatory, antidiabetic, hypolipidemic, and anticancer properties [2-5].

Among spices, cinnamon, cumin, clove, laurel, and black pepper and their derived essential oils are utilized worldwide as flavor, aroma, color, and preservative agents in the food and pharmaceutical industries [3,4].

The inner bark of Cinnamomum verum J.Presl. (syn. Cinnamomum zeylanicum Blume, Lauraceae, cinnamon) is widely used as a spice and flavoring agent in food and industrial products, e.g., baked goods, seasonings, confectionery, candies, chewing gums, drinks, mouthwash, and toothpaste [5,6]. The main compounds identified in cinnamon comprise essential oils (up to $4 \%$ ), condensed tannins, coumarins, flavonoids, lignans, resins, and sterols [7]. Cinnamon has been used since time immemorial in the treatment of different human ailments, such as respiratory disorders (bronchitis, asthma, fever, common cold, and influenza), gastrointestinal upsets (anorexia, dyspepsia, nausea, flatulent colic, infantile diarrhea), inflammation, and headache [8,9]. Modern studies revealed that cinnamon possesses pleiotropic pharmacological effects, including antimicrobial, anthelmintic, antidiabetic, antitumor, anti-inflammatory, analgesic, antidepressant, and neuroprotective activities [10].

The dried flower buds of Syzygium aromaticum (L.) Merr. \& L.M.Perry (syn. Eugenia caryophyllata Thunb., Myrtaceae, clove) are broadly used as a culinary spice and flavoring agent in foods, perfumery, cosmetics, and in the pharmaceutical industry [11,12]. Various classes of phytochemicals have been reported in clove and refer mainly to essential oils (up to 20\%), flavonoids, phenolic acids, ellagitannins, saponins, sterols, and lipids [13,14]. Traditionally, clove is used as a remedy for toothache, mouth and throat inflammation, bronchitis, cough, digestive disorders, rheumatism, and myalgia [15]. The bioactivity of clove extractives has been well-documented and refers to antispasmodic, antifungal, antibacterial, antiviral, antioxidant, anti-inflammatory, antinociceptive, antihistaminic, and anthelmintic properties $[3,14,16]$.

The dried fruits of Cuminum cyminum L. (Apiaceae, cumin) are the main components of curry and chili powders, being largely used in bakery, meat products, soups, snacks, and as a preservative in food processing [17]. The traditional uses of cumin relate to alleviation of digestive complaints (dyspepsia, flatulence, colic, and diarrhea) and stimulation of lactation [18]. The main phytoconstituents found in cumin are essential oils (up to $5 \%$ ), flavonoids, tannins, phenolic acids, and fatty oil [10]. In addition, literature reports show that cumin is endowed with significant pharmacological effects, such as antifungal, antibacterial, antioxidant, antispasmodic, antitumor, anti-inflammatory, hypoglycemic, and hypolipidemic activities [19,20].

The dried leaves of Laurus nobilis L. (Lauraceae, laurel) are a popular spice commonly used in the culinary, food, and fragrance industries [21-23]. The phytochemistry of laurel is characterized by the presence of essential oils (up to 3\%), sesquiterpene lactones, alkaloids, flavonoids, phenolic acids, proanthocyanidins, and fixed oils [24,25]. Since antiquity, laurel has been used against digestive disorders (bloating and flatulence), respiratory infections, cough, and rheumatism [26]. Moreover, recent studies prompted various properties of laurel extractives, e.g., antimicrobial, antioxidant, anti-inflammatory, antidiabetic, insecticidal, trypanocidal, and antitumor $[24,27,28]$.

The unripe dried fruits of Piper nigrum L. (Piperaceae, black pepper) are utilized worldwide as aroma and fragrance agents in culinary dishes [2,29]. Ethnomedicinal uses of piper include menstruation disorders, respiratory infections, fever, gastrointestinal complaints, and skin diseases [30]. The specialized metabolites of black pepper comprise essential 
oils (up to 7\%), alkaloids, flavonoids, lignans, tannins, and anthraquinones [31]. Piper extracts and derived compounds were shown to exert a plethora of biological activities, namely, antimicrobial, antioxidant, anticancer, anti-inflammatory, analgesic, hypoglycemic, hypolipidemic, anticonvulsant, and neuroprotective effects [29,31,32].

In order to meet the needs of industrial applications, these spices are largely cultivated, with Asia, Latin America, United States, Mediterranean, and Continental Europe countries as being the main suppliers [22]. Hydrodistillation (steam or water distillation) is utilized at the industrial scale for the essential spice oil isolation, since it is a low cost, simple, and environmentally safe method [33]. Therefore, large amounts of spent plant materials are derived as by-products from the industrial production of essential oils. This solid biomass is either discarded as waste and sent to landfill, incinerated, or used as compost in agriculture [34,35]. Additional means of re-utilization of such by-products have been proposed, including as antioxidant additives to biodiesel [36] and alternative fuel in electricity generation $[37,38]$.

Literature data on the recovery and valorization of spent plant material from abovementioned spices are scarce, with only several reports documenting the use of their spent plant materials as a source of chemicals, e.g., isolation of piperine from black pepper [39] and nutrients, namely, fibers, lipids, and carbohydrates from cumin [40]. Still, a large number of phytochemicals, such as phenolic acids, flavonoids, alkaloids with significant biological activities might be recovered and used to obtain high value-added products. Previously, several studies have reported on the recovery of phenolic fractions from spent plant materials of culinary herbs and spices and their pharmacological effects. For example, extracts from spent materials of Lavandula $\times$ intermedia Emeric ex Loisel. and Thymus mastichina (L.) L. were shown to possess significant free radical-scavenging activity, metal chelating, and reducing ability [41]. In addition, Cid-Pérez et al. [42] showed that extracts derived from spent material of Mexican oregano (Poliomintha longiflora A.Gray) displayed potent antioxidant and antimicrobial properties.

In this context, the aim of our study was to evaluate the potential valorization of spent plant materials derived after essential oil isolation from five common spices, namely, cinnamon, cumin, clove, laurel, and black pepper. Therefore, after essential oil isolation, the spent plant materials were extracted with solvent of different polarities. The essential oils and extracts were comprehensively characterized by state-of-the-art chromatographic platforms (gas chromatography coupled with mass spectrometry (GC-MS), GC coupled with flame ionization detection (FID), liquid chromatography coupled with high-resolution tandem mass spectrometry (LC-HRMS/MS)). Subsequently, the putative antioxidant effects of the essential oils and spent material derived extracts were assessed by six evaluation methods (1,1'-diphenyl-2-picrylhydrazyl (DPPH) assay, 2,2'-azino-bis(3-ethylbenzothiazoline) 6-sulfonic acid (ABTS) assay, cupric ion reducing antioxidant capacity (CUPRAC) assay, ferric ion reducing antioxidant power (FRAP) assay, ferrous ion chelating ability (MCA) assay, and phosphomolybdenum assay (PBD)). The potential anti-enzymatic activities were evaluated using five in vitro methods (acetylcholinesterase (AChE), butyrylcholinesterase $(\mathrm{BChE})$, tyrosinase, amylase and glucosidase inhibition assays).

\section{Results and Discussion}

\subsection{GC-MS and GC-FID Analysis of Essential Oils Isolated from Different Spices}

The highest essential oil yield, as calculated based on dry plant material weight, was determined for cumin, followed by clove, black pepper, cinnamon, and laurel (Table 1). The phytochemical profile of essential oils obtained by hydrodistillation was assessed by GC analysis (Table 2). 
Table 1. Extraction yields of essential oils and extracts obtained from different spices.

\begin{tabular}{|c|c|}
\hline Sample & Extraction Yield \\
\hline & $(\%)$ \\
\hline \multicolumn{2}{|c|}{ Cinnamon Extracts } \\
\hline $\mathrm{CiH}$ & 0.29 \\
\hline CiD & 0.55 \\
\hline CiMW & 1.71 \\
\hline $\mathrm{CiM}$ & 1.77 \\
\hline CiEO & 3.10 \\
\hline \multicolumn{2}{|c|}{ Cumin Extracts } \\
\hline $\mathrm{CuH}$ & 2.53 \\
\hline $\mathrm{CuD}$ & 3.30 \\
\hline CuMW & 1.94 \\
\hline $\mathrm{CuM}$ & 3.69 \\
\hline CuEO & 7.40 \\
\hline \multicolumn{2}{|c|}{ Clove Extracts } \\
\hline $\mathrm{ClH}$ & 8.98 \\
\hline CID & 14.37 \\
\hline ClMW & 1.36 \\
\hline $\mathrm{ClM}$ & 27.85 \\
\hline CIEO & 7.00 \\
\hline \multicolumn{2}{|c|}{ Laurel Extracts } \\
\hline $\mathrm{LaH}$ & 3.23 \\
\hline $\mathrm{LaD}$ & 4.89 \\
\hline LaMW & 4.82 \\
\hline LaM & 9.03 \\
\hline LaEO & 3.00 \\
\hline \multicolumn{2}{|c|}{ Black Pepper Extracts } \\
\hline BpH & 1.39 \\
\hline BpD & 4.44 \\
\hline BpMW & 2.85 \\
\hline BpM & 8.51 \\
\hline BрEO & 5.80 \\
\hline
\end{tabular}

Abbreviations: BpD—black pepper dichloromethane extract; BpEO—black pepper essential oil; BpH—black pepper hexane extract; BpM-black pepper methanol extract; BpMW—black pepper 50\% aqueous methanol extract; $\mathrm{CiD}$-cinnamon dichloromethane extract; $\mathrm{CiEO}$ — cinnamon essential oil; $\mathrm{CiH}$-cinnamon hexane extract; $\mathrm{CiM}-$ cinnamon methanol extract; CiMW—cinnamon 50\% aqueous methanol extract; CID—clove dichloromethane extract; $\mathrm{ClEO}$ —clove essential oil; $\mathrm{ClH}$-clove hexane extract; $\mathrm{ClM}$ —clove methanol extract; $\mathrm{ClMW}$-clove 50\% aqueous methanol extract; $\mathrm{CuD} —$ cumin dichloromethane extract; $\mathrm{CuEO} —$ cumin essential oil; $\mathrm{CuH}-\mathrm{cumin}$ hexane extract; $\mathrm{CuM}$ — cumin methanol extract; $\mathrm{CuMW}$ — cumin 50\% aqueous methanol extract; LaD-laurel dichloromethane extract; LaEO—laurel essential oil; LaH—laurel hexane extract; LaM-laurel methanol extract; LaMW-laurel $50 \%$ aqueous methanol extract.

In the case of cinnamon essential oil (CiEO), up to $97.16 \%$ of the total constituents were identified, with cinnamaldehyde as the main compound $(64.20 \%)$, followed by cinnamyl acetate $(8.74 \%), \beta$-caryophyllene $(4.61 \%), \beta$-phellandrene $(4.26 \%)$, and eugenol $(3.47 \%)$. Of the total constituents, $97.84 \%$ were identified in cumin essential oil (CuEO); cuminaldehyde and safranal were the major compounds (30.96\% and $29.59 \%$, respectively), alongside $\beta$-pinene $(18.06 \%)$ and $\gamma$-terpinene $(12.21 \%)$. Eugenol $(74.34 \%)$ was the main constituent of clove essential oil (CIEO), followed by $\beta$-caryophyllene (17.89\%), eugenyl acetate $(5.24 \%)$, and $\alpha$-humulene (1.24), together making up to $99.31 \%$ of the total constituents. Laurel essential oil (LaEO) was characterized by the presence of eucalyptol as the major compound $(48.05 \%)$, followed by $\alpha$-terpinyl acetate $(13.36 \%)$ and sabinene $(7.14 \%)$, and other minor constituents, together representing $96.55 \%$ of the total volatile fraction. In black pepper essential oil (BpEO), $99.17 \%$ of the volatile compounds were identified, with $\alpha$-terpinene (24.71\%), limonene (19.90\%), $\beta$-caryophyllene $(17.59 \%)$, and 
$\beta$-pinene (13.16\%) as the main constituents. The profile of the investigated spice essential oils is well-known, literature data abound with phytochemical studies that document their marker compounds. Indeed, the qualitative and quantitative profile of essential oils varies upon several factors, e.g., plant phenotype, pedoclimatic conditions, methods of harvesting, storage conditions, processing, and extraction methods [43,44]. Our data is in agreement with previous reports on marker constituents from cinnamon—cinnamaldehyde, eugenol, $\beta$-caryophyllene, and cinnamyl acetate $[7,8,10]$; clove-eugenol, eugenyl acetate, $\beta$-caryophyllene, and $\alpha$-humulene [11,14]; cumin-cuminaldehyde, $\beta$-pinene, $\gamma$-terpinene, and safranal [10,43]; laurel—eucalyptol (1,8 cineole), sabinene, and $\alpha$-terpinyl acetate [24]; and black pepper- $\beta$-caryophyllene, limonene, and $\alpha$-terpinene [31,45].

Table 2. Chemical composition of essential oils isolated from different spices.

\begin{tabular}{|c|c|c|c|}
\hline No. & $\mathbf{R I} *$ & Compound & $(\%)$ \\
\hline \multicolumn{4}{|c|}{ Cinnamon Essential Oil } \\
\hline 1. & 937 & $\alpha$-pinene & 1.05 \\
\hline 2. & 1008 & $\alpha$-phellandrene & 1.79 \\
\hline 3. & 1019 & $\alpha$-terpinene & 0.92 \\
\hline 4. & 1027 & m-cymene & 1.31 \\
\hline 5. & 1039 & $\beta$-phellandrene & 4.26 \\
\hline 6. & 1102 & Linalool & 2.83 \\
\hline 7. & 1293 & Cinnamaldehyde & 64.20 \\
\hline 8. & 1368 & Eugenol & 3.47 \\
\hline 9. & 1433 & $\beta$-caryophyllene & 4.61 \\
\hline 10. & 1457 & Cinnamyl acetate & 8.74 \\
\hline 11. & 1465 & $\alpha$-humulene & 0.82 \\
\hline 12. & 1535 & Methoxycinnamaldehyde & 0.60 \\
\hline \multirow[t]{3}{*}{13.} & 1775 & Benzyl benzoate & 2.56 \\
\hline & & Total & 97.16 \\
\hline & & \multicolumn{2}{|l|}{ Cumin Essential Oil } \\
\hline 1. & 937 & $\alpha$-pinene & 0.99 \\
\hline 2. & 976 & Sabinene & 0.92 \\
\hline 3. & 984 & $\beta$-pinene & 18.06 \\
\hline 4. & 992 & Myrcene & 1.08 \\
\hline 5. & 1028 & $m$-cymene & 2.67 \\
\hline 6. & 1066 & $\gamma$-Terpinene & 12.21 \\
\hline 7. & 1180 & Terpinen-4-ol & 1.39 \\
\hline 8. & 1255 & Cuminaldehyde & 30.93 \\
\hline \multirow[t]{3}{*}{9.} & 1304 & Safranal & 29.59 \\
\hline & & Total & 97.84 \\
\hline & & \multicolumn{2}{|l|}{ Clove Essential Oil } \\
\hline 1. & 1369 & Eugenol & 74.34 \\
\hline 2. & 1439 & $\beta$-caryophyllene & 17.89 \\
\hline 3. & 1466 & $\alpha$-humulene & 1.84 \\
\hline \multirow[t]{2}{*}{4.} & 1535 & Eugenyl acetate & 5.24 \\
\hline & & Total & 99.31 \\
\hline
\end{tabular}


Table 2. Cont.

\begin{tabular}{|c|c|c|c|}
\hline No. & $\mathbf{R I} *$ & Compound & $(\%)$ \\
\hline \multicolumn{4}{|c|}{ Laurel Essential Oil } \\
\hline 1. & 938 & $\alpha$-pinene & 6.29 \\
\hline 2. & 952 & Camphene & 0.97 \\
\hline 3. & 979 & Sabinene & 7.14 \\
\hline 4. & 984 & $\beta$-Pinene & 4.95 \\
\hline 5. & 1037 & Eucalyptol & 48.05 \\
\hline 6. & 1061 & $\gamma$-Terpinene & 0.72 \\
\hline 7. & 1102 & Linalool & 2.37 \\
\hline 8. & 1183 & Terpinen-4-ol & 3.03 \\
\hline 9. & 1196 & $\alpha$-terpineol & 1.85 \\
\hline 10. & 1289 & Bornyl acetate & 1.02 \\
\hline 11. & 1319 & $\Delta$-terpinyl acetate & 0.88 \\
\hline 12. & 1359 & $\alpha$-terpinyl acetate & 13.36 \\
\hline 13. & 1365 & Eugenol & 2.24 \\
\hline 14. & 1407 & Methyleugenol & 3.04 \\
\hline \multirow[t]{3}{*}{15.} & 1587 & Spathulenol & 0.64 \\
\hline & & Total & 96.55 \\
\hline & \multicolumn{3}{|c|}{ Black Pepper Essential Oil } \\
\hline 1. & 940 & $\alpha$-pinene & 10.56 \\
\hline 2. & 984 & $\beta$-pinene & 13.16 \\
\hline 3. & 994 & Myrcene & 3.10 \\
\hline 4. & 1014 & $\alpha$-phellandrene & 5.05 \\
\hline 5. & 1018 & $\alpha$-terpinene & 24.71 \\
\hline 6. & 1037 & Limonene & 19.90 \\
\hline 7. & 1092 & $\alpha$-terpinolene & 0.89 \\
\hline 8. & 1343 & $\Delta$-elemene & 1.17 \\
\hline 9. & 1383 & Copaene & 1.17 \\
\hline 10. & 1435 & $\beta$-caryophyllene & 17.59 \\
\hline 11. & 1490 & Germacrene D & 1.06 \\
\hline \multirow[t]{2}{*}{12.} & 1504 & $\alpha$-selinene & 0.82 \\
\hline & & Total & 99.17 \\
\hline
\end{tabular}

* Retention indices relative to a series of C8-C20 n-alkanes calculated on TRB-5MS column.

\subsection{LC-HRMS/MS Analysis of Extracts Obtained from Different Spices}

The spice spent materials obtained after essential oil isolation were extracted with solvents with different polarities (hexane, dichloromethane, methanol, and 50\% aqueous methanol) (Table 1 ) and phytochemically profiled by LC-HRMS/MS (Table 3). For all samples, the highest extraction yields were provided by methanol, reinforcing the well-known ability of this solvent to efficiently solubilize both lipophilic and hydrophilic constituents [46].

Twelve specialized metabolites were putatively labeled in the cinnamon extracts, with seven organic and phenolic acids (quinic, gluconic, vanillic, citric, ferulic, caffeoylquinic, and hydroxybenzoic acids), two proanthocyanidins (one monomer, (epi)catechin, and one trimer), and two fatty acids (trihydroxy- and dihydroxy-octadecenoic acids). Previous profiling studies revealed a more complex chemical composition of various cinnamon extracts obtained from unprocessed materials. For instance, Vallverdú-Queralt et al. [47] reported the presence of several phenolic acids (gallic, syringic, hydroxybenzoic, vanillic, chlorogenic, neochlorogenic, cryptochlorogenic, ferulic, rosmarinic, coumaroylquinic, and dicaffeoylquinic acids; $\mathrm{O}$-hexosides of homovanillic, caffeic, and coumaric acids, proanthocyanidins (catechin, epicatechin, proanthocyanidin trimers and hexamers) and flavonoids (free aglycons and $O$ - or $C$-glycosides of quercetin, kaempferol, naringenin and hesperitin) in a 50\% aqueous ethanol cinnamon extract. In another study, 28 specialized metabolites (hydroxybenzoic acids, hydroxycinnamic acids, hydroxyphenylacetic acids, flavanols, flavones, flavonols, isoflavonoids, curcuminoids, tyrosols, and lignans) were tentatively identified in a 70\% aqueous ethanol cinnamon extract [48]. 
With respect to the cumin extracts, eleven constituents were annotated; some of them (citric acid, coniferol-O-hexoside) were already noticed in the cinnamon extracts. In contrast, the flavonoid profile was slightly more complex, with seven luteolin and apigenin derivatives, such as free aglycons, $\mathrm{O}$-hexosides, acetylhexosides or hexuronide-hexosides; additionally, two hydroxycinnamic acid derivatives were observed (Table 3). Previously, Ali et al. [48] reported around 24 constituents in a 70\% aqueous ethanol cumin extract, whereas Vallverdú-Queralt et al. [47] described 34 different chemical entities in the 50\% aqueous ethanol cumin extract; the most notable compounds belonged to the phenolic acids and flavonoids (flavanols, flavones, flavonols), which is in agreement with the results from the current study.

The LC-HRMS/MS analysis of clove extracts revealed the presence of 19 constituents; beside the common organic acid derivatives, such as quinic, gallic, and citric acids, several specific metabolites were tentatively labeled (Table 3). For instance, hydroxycinnamic acids and flavonoids were represented by twelve derivatives (caffeoylquinic acids I and II, quercetin, isorhamnetin and their $O$-glycosides, luteolin, chrysoeriol, cirsiliol, cirsimaritin). On the other hand, hydrolysable tannins, namely, ellagic acid, trimethylellagic acid, di- and tri-O-galloylhexahydroxydiphenoyl-hexoses, were retrieved as distinguishable clove constituents. Previously, Ali et al. [48] documented around 20 different phenolic acids and flavonoids in the $70 \%$ aqueous ethanol clove extract. Duyen $\mathrm{Vu}$ et al. [49] reported the characterization of 28 compounds (11 flavonoids, 13 triterpene acids, and four phenolic acids) in a 70\% aqueous ethanol clove extract of Syzygium formosum (Wall.) Masam, whereas Peixeto Araujo et al. [50] described 153 phytochemicals from different classes, including organic acids, phenolic acids, flavonoids, in the leaves, pulp and seed extracts of Eugenia calycina Cambess. Rummun et al. [51] revealed the presence of 59 metabolites, which consisted mostly of phenolic acids, flavonoids, and hydrolysable tannins, in the leaf extracts of Syzygium coriaceum Bosser \& J. Gueho.

Except for citric acid, caffeoylquinic acid, gallic acid-O-hexoside, and a proanthocyanidin trimer, the remaining 11 compounds tentatively identified in the laurel extracts were derivatives of quercetin, isorhamnetin, and kaempferol (Table 3). Our data is in agreement with the study of Pacifico et al. [52] who documented the presence of 21 diverse flavonoids and proanthocyanidins in the methanolic laurel leaf extracts and that of Bourebaba et al. [53] in which 15 phenolic acids and flavonoids were labeled in the ethanol laurel leaf extracts. It is worth mentioning that three acylated kaempferol glycosides (La11-La13) were previously reported only by Fiorini et al. [54] in a 70\% aqueous ethanol extract of laurel leaves.

Lastly, the LC-HRMS/MS metabolite profiling of the black pepper extracts revealed a totally different chemical composition, as compared to other four spices, with 26 out of a total of 30 tentatively labeled compounds represented by piperamides (Table 3). Among them, piperine, piperlonguminine, pellitorine, pipernonaline, retrofractamide $\mathrm{B}$, guineensine, and $N$-isobutyldodecadienamide are some of the most notable congeners. A similar chemical composition was documented in previous literature data for different black pepper extracts [55-57].

To sum up, the LC-HRMS/MS analysis of the extracts obtained with solvents with different polarities from the plant materials after hydrodistillation (usually discarded as waste products by the essential oil industry) revealed the presence of a diverse range of bioactive phytochemicals. Nevertheless, the adequate extraction solvent should be selected considering the category of phytochemicals as well as the bioactivities that are targeted; for instance, our data (Table 3) showed that cinnamon, cumin, clove, and laurel contained numerous polar flavonoids and phenolics, which were present almost exclusively in the methanol and 50\% aqueous methanol extracts, whereas black pepper was rich in non-polar piperamides, easily extractible with hexane, dichloromethane, or methanol. Overall, as compared to previously literature data, the LCHRMS/MS analysis revealed a lesser phenolic profile of the investigated spices; such differences could be due not only to the extraction conditions (processed/spent vs. unprocessed material), but also to plant phenotype, pedoclimatic conditions, harvesting, and storage conditions. 
Table 3. LC-HRMS/MS data of compounds tentatively identified in different spice extracts.

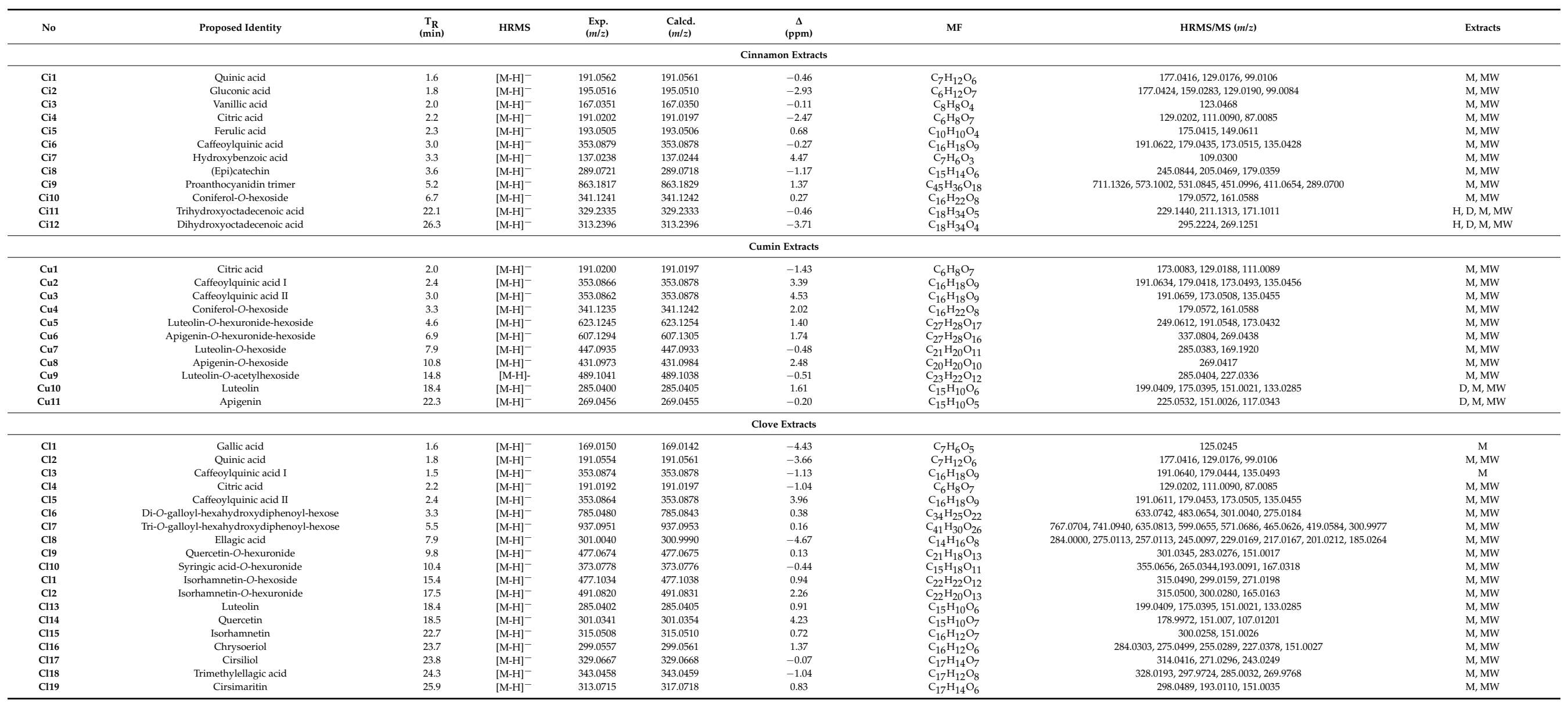


Table 3. Cont.

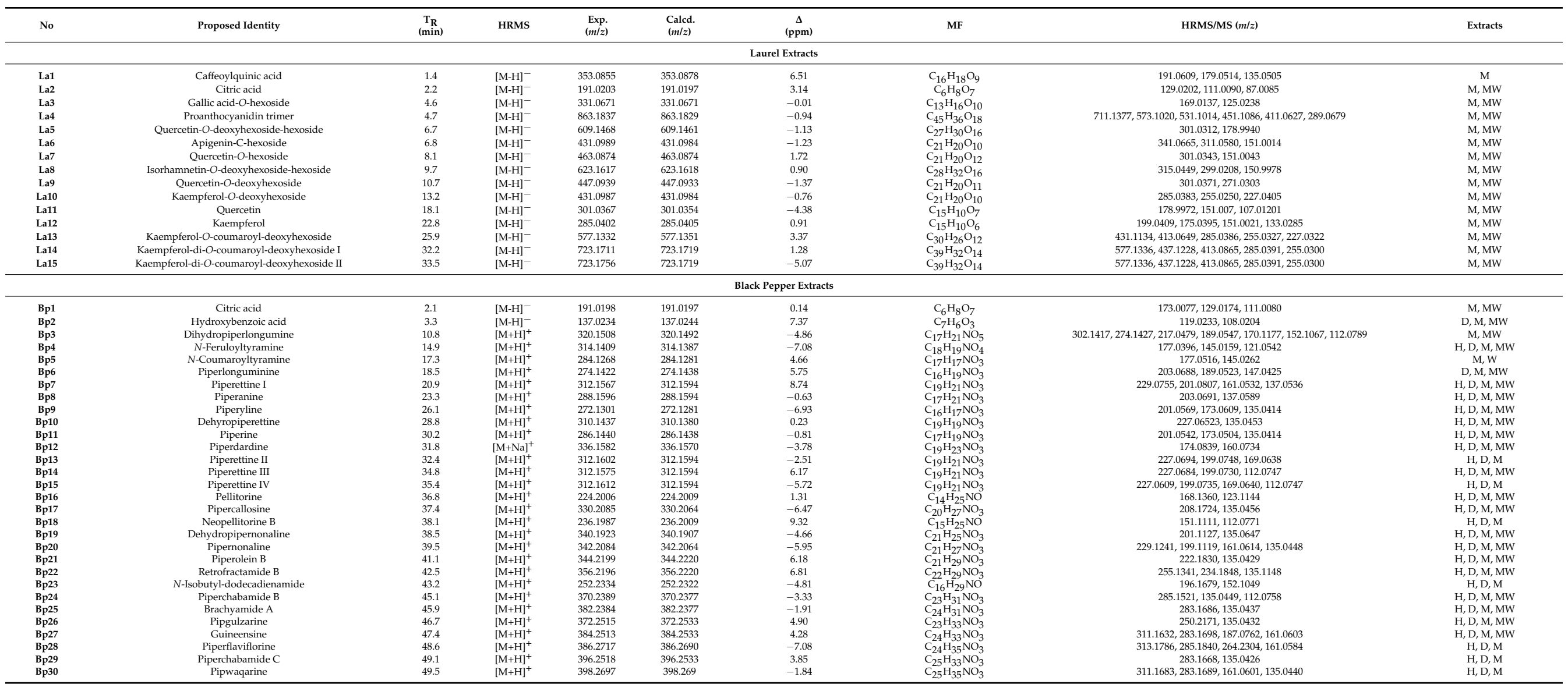

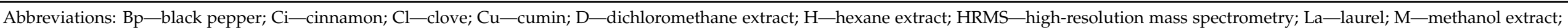
$\mathrm{MF}-$ molecular formula; $\mathrm{MW}-50 \%$ aqueous methanol extract; $\mathrm{T}_{\mathrm{R}}-$ retention time; $\Delta-$ mass error. 


\subsection{Total Phenolic and Flavonoid Content of Extracts Obtained from Different Spices}

The spice residue extracts obtained after the essential oil isolation were next evaluated with respect to their total phenolic content (TPC) and total flavonoid content (TFC) (Table 4). In the cinnamon extracts, TPC varied between $14.00 \mathrm{mg}$ gallic acid equivalents (GAE)/g extract (CiD) and $92.90 \mathrm{mg} \mathrm{GAE} / \mathrm{g}$ (CiMW), whereas TFC ranged from $1.76 \mathrm{mg}$ rutin equivalents (RE)/g extract (CiMW) and $9.83 \mathrm{mg}$ RE/g [58]. According to the existing literature data, total phenolics levels retrieved in our samples are significantly lower than those previously reported in the $50 \%$ aqueous acetone, $80 \%$ aqueous methanol, or aqueous cinnamon extracts (148-309 $\mathrm{mg}$ GAE/g) [59,60]. Cumin extracts displayed TPC from $7.86(\mathbf{C u H})$ to $30.77 \mathrm{mg} \mathrm{GAE} / \mathrm{g}(\mathbf{C u M W})$, with a significantly higher TFC, especially for the polar extracts (50.68 mg RE/g in CuM and $66.25 \mathrm{mg}$ RE/g in CuMW); these two extracts also showed the highest flavonoid levels from all analyzed spices (Table 4). A similar trend was previously observed by Gupta [61] with a reported TPC of $12.15 \mathrm{mg} \mathrm{GAE} / \mathrm{g}$ and $46.56 \mathrm{mg}$ quercetin equivalents/g in a methanol cumin extract. On the other hand, Rebey et al. [62] showed TPC and TFC between 1.09 and 18.60 $\mathrm{mg} \mathrm{GAE} / \mathrm{g}$ and $0.52-5.91 \mathrm{mg}$ catechin equivalents/g, respectively, in cumin extracts obtained with solvents with different polarities (ethanol, methanol, acetone, water, $80 \%$ acetone, $80 \%$ methanol, 80\% ethanol); generally, the hydro-organic extracts showed superior TPC and TFC, which is in agreement with the results from our study.

All four clove extracts displayed the highest TPC (90.67-103.76 mg GAE/g) of all analyzed spices; in contrast, TFC was significantly lower, especially in the non-polar extracts (1.43 mg RE/g in ClH and $5.89 \mathrm{mg} \mathrm{RE} / \mathrm{g}$ in ClD), suggesting that the contribution to TPC values is not due to the presence of flavonoids. Previous reports showed even higher TPC for various aqueous, ethanol, or methanol clove extracts (212.85-425.04 mg GAE/g) [59,61], whereas the levels of flavonoids (4.70-17.5 mg quercetin equivalents/g) in polar clove extracts [63] were significantly lower than the one reported in the current study (41.71 $\mathrm{mg} \mathrm{RE} / \mathrm{g}$ in ClMW and $31.00 \mathrm{mg} \mathrm{RE} / \mathrm{g}$ in ClM). With respect to the laurel extracts, TPC varied from 22.49 (LaH) to $75.53 \mathrm{mg}$ GAE/g (LaMW), whilst TFC varied from 0.50 (LaH) to $27.33 \mathrm{mg}$ RE/g (LaM). Previous data revealed a high variability of the phenolics profile, with TPC ranging from 30.73 to $135.47 \mathrm{mg}$ GAE/g for laurel extracts obtained with polar solvents (methanol/ethanol-water) under different extraction conditions (heat-reflux, ultrasound-assisted, microwave-assisted, mechanochemical-assisted) $[64,65]$. Lastly, black pepper extracts showed a homogenous TPC trend, with amounts between $31.50(\mathbf{B p H})$ and $37.01 \mathrm{mg} \mathrm{GAE} / \mathrm{g}$ (BbMW); a significantly lower TFC, ranging from 2.31 (BpMW) and $6.97 \mathrm{mg}$ RE/g (BpM), was noticed. These results are in agreement with previous literature reports; for instance, different black pepper methanolic extracts displayed total phenolics and flavonoids levels between 36.71 and $58.90 \mathrm{mg} \mathrm{GAE} / \mathrm{g}$ and 5.42 and $18.37 \mathrm{mg} \mathrm{RE} / \mathrm{g}$, respectively $[56,66]$.

Overall, our data suggest that the spent plant materials after essential oil isolation can be confidently used for the efficient recovery of phenolics and flavonoids; a high extractability of these categories of phytochemicals could be a good indicator for a wide range of biological activities with putative applications in the management of diverse chronic diseases. 
Table 4. TPC and TFC of different spice extracts.

\begin{tabular}{|c|c|c|}
\hline Sample & TPC & TFC \\
\hline & (mg GAE/g) & (mg RE/g) \\
\hline \multicolumn{3}{|c|}{ Cinnamon Extracts } \\
\hline $\mathrm{CiH}$ & $18.46 \pm 0.27^{\mathrm{c}}$ & $3.88 \pm 0.02^{b}$ \\
\hline CiD & $14.00 \pm 0.15^{\mathrm{d}}$ & $3.27 \pm 0.14^{\mathrm{c}}$ \\
\hline CiMW & $92.90 \pm 0.46^{\mathrm{a}}$ & $1.76 \pm 0.11^{\mathrm{d}}$ \\
\hline CiM & $63.68 \pm 1.48^{b}$ & $9.83 \pm 0.09^{a}$ \\
\hline \multicolumn{3}{|c|}{ Cumin Extracts } \\
\hline $\mathrm{CuH}$ & $7.86 \pm 0.11^{d}$ & $0.48 \pm 0.05^{\mathrm{cd}}$ \\
\hline CuD & $9.75 \pm 0.07^{\mathrm{d}}$ & $0.72 \pm 0.05^{\mathrm{c}}$ \\
\hline CuMW & $30.77 \pm 0.38^{a}$ & $66.25 \pm 0.33^{a}$ \\
\hline $\mathrm{CuM}$ & $19.69 \pm 0.54^{b}$ & $50.68 \pm 0.41^{b}$ \\
\hline \multicolumn{3}{|c|}{ Clove Extracts } \\
\hline $\mathrm{ClH}$ & $100.86 \pm 0.59^{b}$ & $1.43 \pm 0.06^{\mathrm{d}}$ \\
\hline ClD & $90.67 \pm 1.24^{\mathrm{d}}$ & $5.89 \pm 0.12^{\mathrm{c}}$ \\
\hline ClMW & $103.76 \pm 0.23^{a}$ & $41.71 \pm 0.13^{\mathrm{a}}$ \\
\hline $\mathrm{ClM}$ & $94.46 \pm 0.53^{c}$ & $31.00 \pm 0.25^{b}$ \\
\hline \multicolumn{3}{|c|}{ Laurel Extracts } \\
\hline $\mathrm{LaH}$ & $22.49 \pm 0.31^{\mathrm{d}}$ & $0.50 \pm 0.07^{c}$ \\
\hline $\mathrm{LaD}$ & $24.29 \pm 0.18^{c}$ & $0.55 \pm 0.02^{\mathrm{c}}$ \\
\hline LaMW & $75.53 \pm 0.10^{\mathrm{a}}$ & $19.50 \pm 0.25^{b}$ \\
\hline LaM & $48.95 \pm 0.32^{b}$ & $27.33 \pm 0.40^{\mathrm{a}}$ \\
\hline \multicolumn{3}{|c|}{ Black Pepper Extracts } \\
\hline BpH & $31.50 \pm 0.14^{\mathrm{d}}$ & $6.78 \pm 0.59^{c}$ \\
\hline BpD & $33.51 \pm 0.10^{\mathrm{c}}$ & $8.64 \pm 0.35^{b}$ \\
\hline BpMW & $37.01 \pm 0.15^{\mathrm{a}}$ & $2.31 \pm 0.21^{\mathrm{d}}$ \\
\hline BрM & $35.42 \pm 0.13^{b}$ & $9.67 \pm 0.28^{a}$ \\
\hline
\end{tabular}

Data are presented as mean \pm standard deviation (SD) of three determinations; different superscript letters within columns indicate significant differences in the tested extracts for the same species $(p<0.05)$. Abbreviations: $\mathrm{BpD}$-black pepper dichloromethane extract; $\mathrm{BpH}$-black pepper hexane extract; $\mathrm{BpM}$-black pepper methanol extract; $\mathrm{BpMW}$-black pepper $50 \%$ aqueous methanol extract; $\mathrm{CiD}$ - cinnamon dichloromethane extract; $\mathrm{CiH}$ cinnamon hexane extract; CiM - cinnamon methanol extract; CiMW—cinnamon 50\% aqueous methanol extract; $\mathrm{ClD}$ —clove dichloromethane extract; $\mathrm{ClH}$-clove hexane extract; $\mathrm{ClM}$-clove methanol extract; $\mathrm{ClMW}$-clove $50 \%$ aqueous methanol extract; $\mathrm{CuD}-$ cumin dichloromethane extract; $\mathrm{CuH}-$ cumin hexane extract; $\mathrm{CuM}-$ cumin methanol extract; CuMW—cumin 50\% aqueous methanol extract; GAE—gallic acid equivalents; LaD—laurel dichloromethane extract; $\mathrm{LaH}$-laurel hexane extract; LaM-laurel methanol extract; LaMW—laurel 50\% aqueous methanol extract; RE—rutin equivalents; TFC—-total flavonoid content; TPC—-total phenolic content.

\subsection{Antioxidant Activity of Extracts and Essential Oils Obtained from Different Spices}

The antioxidant properties of spices are largely known; besides their common use as food preservatives, spices display additional health benefits in the prevention and complementary treatment of oxidative stress-related disorders (e.g., cardiovascular diseases, neurodegenerative diseases, gastro-intestinal disorders, and cancers) $[1,67]$. Polyphenols and terpenoids are considered the main antioxidant compounds from spices that act as radical scavenging, reducing power, and metal chelating agents [3]. To evaluate the antioxidant capacity of the essential oils and their spent plant material extracts, several in vitro methods were undertaken, namely, 1,1'-diphenyl-2-picrylhydrazyl (DPPH) assay, 2,2'-azino-bis(3-ethylbenzothiazoline) 6-sulfonic acid (ABTS) assay, cupric ion reducing antioxidant capacity (CUPRAC) assay, ferric ion reducing antioxidant power (FRAP) assay, ferrous ion chelating ability (MCA) assay, and phosphomolybdenum assay (PBD). The obtained results are summarized in Table 5. By using an integrative approach, we report herein for the first time the antioxidant effects of spent spice material extracts derived after essential oil hydrodistillation from cinnamon, cumin, clove, laurel, and black pepper. In 
order to illustrate that the spent spice material is a valuable source of phytochemicals, we compared our results with literature data on unprocessed plant material. Still, even though several studies assessed the antioxidant potential of investigated spices, a direct comparison between the results obtained in the present study and literature data is hampered as a consequence of the implementation of different protocols and various ways of expressing the results.

All investigated extracts displayed variable radical scavenging abilities, as assessed by the DPPH and ABTS assays. Thus, cinnamon extracts showed significant radical scavenging effects, with CiMW exhibiting the highest activity in the DPPH test and CiEO in the ABTS assay (210.00 and $839.94 \mathrm{mg}$ Trolox equivalents (TE)/g, respectively). The polar extracts (CiMW and CiM) were the most effective as scavenging agents, while the nonpolar extracts ( $\mathbf{C i H}$ and $\mathbf{C i D}$ ) were significantly less active (Table 5). A similar trend was observed by Saranya et al. [68], when the anti-DPPH radical effects of cinnamon extracts decreased in the following order: methanol $\left(\mathrm{IC}_{50}=11.9 \mu \mathrm{g} / \mathrm{mL}\right)>$ chloroform $\left(\mathrm{IC}_{50}=166.3\right.$ $\mu \mathrm{g} / \mathrm{mL})>$ hexane $\left(\mathrm{IC}_{50}=689.2 \mu \mathrm{g} / \mathrm{mL}\right)$. Regarding the cumin extracts, CuMW displayed the highest DPPH and ABTS radical scavenging potency, with values of 46.39 and 77.14 $\mathrm{mg} \mathrm{TE} / \mathrm{g}$, respectively. The non-polar extracts were less potent, while CuEO showed no activity in the DPPH assay. All clove extracts were significantly effective as radical scavengers, with CIEO exhibiting the highest activity towards DPPH and ABTS radicals among investigated spices (values of 525.78 and $936.44 \mathrm{mg} \mathrm{TE} / \mathrm{g}$, respectively) (Table 5). In addition, the spent material extracts were shown to exhibit anti-radical effects, with values ranging from 355.23 (CID) to $488.45 \mathrm{mg}$ TE/g (CIMW) in the DPPH test, and from 669.32 (CID) to $770.12 \mathrm{mg}$ TE/g (CIMW) in the ABTS assay. Previously, clove essential oil was reported to scavenge DPPH and ABTS radicals in a similar extent $\left(\mathrm{EC}_{50}\right.$ values of 0.40 and $0.42 \mathrm{mg} / \mathrm{mL}$, respectively) to an ethanol extract $\left(\mathrm{EC}_{50}\right.$ values of 0.41 and $0.43 \mathrm{mg} / \mathrm{mL}$, respectively) [69]. The DPPH scavenging ability of laurel extracts varied between $2.08 \mathrm{mg}$ $\mathrm{TE} / \mathrm{g}(\mathbf{L a H})$ and $194.14 \mathrm{mg}$ TE/g (LaMW), while LaEO exhibited the highest activity in the ABTS assay (507.33 mg TE/g). Speroni et al. [70] documented the radical quenching capacity of methanol and chloroform laurel extracts (DPPH: IC 50 of 38 and $155 \mu \mathrm{g} / \mathrm{mL}$; ABTS: 0.65 and $0.21 \mathrm{mmol} \mathrm{TE} / \mathrm{g})$. Within the black pepper extracts, the polar extracts BpMW and BpM were the most effective in scavenging synthetic radicals (DPPH: 45.41 and $32.41 \mathrm{mg}$ TE/g; ABTS: 76.59 and $49.88 \mathrm{mg}$ TE/g), followed by the non-polar extracts, $\mathbf{B p H}$ and BpD. In contrast, BpEO was less active compared to other extracts in the two assays (Table 5). In our previous study, we reported a similar radical quenching ability for the methanol extracts derived from Piper sp. (63.67-82.44 mg TE/g in DPPH assay and 61.63-77.60 mg TE/g in ABTS assay) [56].

The reducing potential, as assessed by CUPRAC and FRAP methods, varied largely between the investigated extracts. In the case of cinnamon extracts, their ability to reduce transition metals displayed a similar pattern and decreased in the following order: CiEO > $\mathrm{CiMW}>\mathrm{CiM}>\mathrm{CiD}>\mathrm{CiH}$, with the highest potential at $762.89 \mathrm{mg} \mathrm{TE} / \mathrm{g}$ and $834.77 \mathrm{mg} \mathrm{TE} / \mathrm{g}$ in the CUPRAC and FRAP assays, respectively. Moreover, the polar extracts showed greater electron donor capacity as compared to the non-polar extracts (Table 5). Similarly, previous reports on cinnamon extracts demonstrated their power reducing ability, with methanol extracts being more potent ferric ion reducers ( 0.74 molar ascorbic acid equivalents (MAAE) $/ \mathrm{g}$ ) when compared to non-polar solvent extractives, e.g., hexane (0.28 MAAE/g) [68]. Among the cumin extracts, the most effective reducing agents were found to be CuMW (118.66 mg TE/g) and CuEO (87.71 mg TE/g) in the CUPRAC and FRAP assays, respectively. The reducing potential of cumin essential oil and methanol extract were previously assessed by Einafshar et al. [71] using the FRAP method (459.4 and $18.47 \mathrm{mmol} \mathrm{Fe}^{2+} / \mathrm{g}$, respectively). Clove extracts displayed a noticeable reducing power, with ClEO being the most active among all investigated spices (2848.28 mg TE/g and $1927.98 \mathrm{mg}$ TE/g in the CUPRAC and FRAP assays, respectively). Nonetheless, the spent spice material extracts exhibited significant reducing potential, that varied between 753.39 (CID) and $978.08 \mathrm{mg}$ TE/g (CIMW) in the CUPRAC assay, and from $876.30(\mathrm{ClM})$ to $1209.92 \mathrm{mg} \mathrm{TE} / \mathrm{g}(\mathbf{C l H})$ in the FRAP assay. Compared to clove, laurel extracts 
were less active as transition metal reductants (Table 5). Their reducing power varied with a similar pattern in both assays, increasing from 28.58 (LaH) to $416.67 \mathrm{mg} \mathrm{TE} / \mathrm{g}$ (LaEO) in the CUPRAC test, and between $14.11(\mathrm{LaH})$ and $435.97 \mathrm{mg}$ TE/g (LaEO) in the FRAP test. Besides, the polar fractions were more active compared to non-polar extracts, displaying up to a 10-fold and 14-fold activity increase in the CUPRAC and FRAP assays, respectively (Table 5). In accordance to our study, Carlsen et al. [72] reported superior reducing effects for clove compared to laurel $50 \%$ methanol extracts as evaluated by FRAP method ( $273.3 \mathrm{vs.} 27.8 \mathrm{mmol} \mathrm{TE} / 100 \mathrm{~g}$ ). The reducing properties of black pepper extracts varied from 51.22 (BpM) to $176.06 \mathrm{mg}$ TE/g (BpEO) in the CUPRAC assay, while in the FRAP assay activity values from 14.11 (LaH) to $435.97 \mathrm{mg}$ TE/g (LaEO) were noticed. In our previous study on Piper species, the methanolic extracts were shown to be active in both CUPRAC and FRAP assays, their reducing capacity varying from 37.36 to $140.52 \mathrm{mg} \mathrm{TE} / \mathrm{g}$, and from 16.05 to $77.00 \mathrm{mg}$ TE/g, respectively [56]. Moreover, a comprehensive report on antioxidant effects of 39 spices revealed the reducing potency (as evaluated by CUPRAC method) of methanol extracts obtained from cinnamon (53.65 mg TE/g), cumin (1.71 mg TE/g), clove (54.47 mg TE/g), laurel (11.34 mg TE/g), and black pepper (2.09 mg TE/g) [73].

With respect to metal chelation capacity, the analyzed extracts showed variable degrees of potency, with LaEO displaying the highest potency (33.78 mg EDTAE/g), followed by BpMW (30.51 mg EDTAE/g), CuMW (26.96 mg EDTAE/g), CIMW (22.78 mg EDTAE/g), and lastly, $\mathrm{CiH}$ (20.46 mg EDTAE/g). It was shown that the residual water derived from laurel essential oil distillation possesses notable chelating ability (16 mg EDTAE/g). Using similar experimental settings, Luca et al. [56] found that black pepper methanolic extracts acted as iron chelators (12.35-21.54 mg EDTAE/g). Hydroalcoholic cumin extracts were reported to have iron-chelating effects, with $\mathrm{IC}_{50}$ values ranging from 29.35 to 35.46 $\mathrm{mg} / \mathrm{mL}$ [74]. Gülçin et al. [75] found that water and ethanol clove extracts at $60 \mu \mathrm{g} / \mathrm{mL}$ displayed a chelating capacity of $84 \%$ and $88 \%$, respectively.

Regarding the total antioxidant capacity evaluated by the PBD assay, the essential oils displayed the highest potential, with values from 18.26 (CiEO) to $68.19 \mathrm{mmol} \mathrm{TE} / \mathrm{g}$ (ClEO). Concerning the spent spice material extracts, the obtained values were similar to each other within the same species. Thus, clove extracts were prompted as being the most active in the PBD test, their total antioxidant activity varying from $4.38(\mathrm{ClM})$ to $6.02 \mathrm{mmol}$ $\mathrm{TE} / \mathrm{g}(\mathrm{ClH})$. Cinnamon and laurel extracts also showed good antioxidant capacity in the PBD assay (1.22-2.14 mmol TE/g and 1.99-2.07 mmol TE/g, respectively). According to recent literature data, a cinnamon methanol extract was shown to exhibit a total antioxidant ability of $149.15 \mathrm{mg} \mathrm{GAE} / \mathrm{g}$ [76]. Albayrak et al. [77] studied the total antioxidant activity of laurel extracts and found that it decreased in the following order: methanol (196.98 mg ascorbic acid equivalents (AAE)/g) > infusion (69.50 mg AAE/g) > decoction (35.65 $\mathrm{mg}$ AAE/g). Contrarily, cumin and black pepper extracts exhibited the lowest potencies among all spices, with activity values below $1.35 \mathrm{mmol}$ TE/g (Table 5). Previously, the total antioxidant potency of hydroalcoholic cumin extracts varied between 8.25-11.24 $\mathrm{mg} / \mathrm{mL}$ [78]. In one of our previous studies, we showed that a black pepper methanol extract had a total antioxidant capacity of $1.24 \mathrm{mmol} \mathrm{TE} / \mathrm{g}$ [56]. 
Table 5. Antioxidant activity of different spice extracts and essential oils.

\begin{tabular}{|c|c|c|c|c|c|c|}
\hline Sample & DPPH & ABTS & CUPRAC & FRAP & MCA & PBD \\
\hline & \multicolumn{4}{|c|}{ (mg TE/g) } & (mg EDTAE/g) & (mmol TE/g) \\
\hline \multicolumn{7}{|c|}{ Cinnamon Extracts } \\
\hline $\mathrm{CiH}$ & $6.96 \pm 0.41^{d}$ & $21.03 \pm 0.55^{\mathrm{d}}$ & $21.17 \pm 0.25^{\mathrm{e}}$ & $10.60 \pm 1.05^{\mathrm{e}}$ & $20.46 \pm 0.37^{a}$ & $1.66 \pm 0.09^{c}$ \\
\hline CiD & $9.39 \pm 0.57^{\mathrm{d}}$ & $20.01 \pm 0.55^{\mathrm{d}}$ & $47.98 \pm 0.42^{\mathrm{d}}$ & $26.54 \pm 4.83^{\mathrm{d}}$ & $4.86 \pm 0.13^{c}$ & $1.22 \pm 0.04^{\mathrm{d}}$ \\
\hline CiMW & $473.74 \pm 1.45^{c}$ & $588.97 \pm 6.34^{c}$ & $623.44 \pm 5.09^{b}$ & $380.73 \pm 4.96^{b}$ & $19.72 \pm 0.60^{\mathrm{ab}}$ & $2.14 \pm 0.08^{b}$ \\
\hline CiM & $178.42 \pm 0.81^{\mathrm{a}}$ & $235.58 \pm 2.04^{b}$ & $257.93 \pm 8.49^{c}$ & $168.96 \pm 7.49^{c}$ & $16.31 \pm 0.43^{b}$ & $1.67 \pm 0.04^{\mathrm{c}}$ \\
\hline CiEO & $210.00 \pm 2.39^{b}$ & $839.94 \pm 1.89^{a}$ & $762.89 \pm 13.47^{a}$ & $834.77 \pm 1.46^{a}$ & $18.20 \pm 4.51^{\mathrm{ab}}$ & $18.26 \pm 0.29^{a}$ \\
\hline \multicolumn{7}{|c|}{ Cumin Extracts } \\
\hline $\mathrm{CuH}$ & $0.44 \pm 0.03^{\mathrm{d}}$ & $5.07 \pm 0.36^{d}$ & $22.77 \pm 0.27^{\mathrm{d}}$ & $14.81 \pm 2.17^{\mathrm{d}}$ & $4.82 \pm 0.41^{c}$ & $0.60 \pm 0.06^{c}$ \\
\hline $\mathrm{CuD}$ & $1.53 \pm 0.05^{\mathrm{c}}$ & $5.29 \pm 0.28^{\mathrm{d}}$ & $17.57 \pm 0.86^{\mathrm{e}}$ & $12.54 \pm 2.81^{\mathrm{d}}$ & n.a. & $0.61 \pm 0.01^{\mathrm{c}}$ \\
\hline CuMW & $46.39 \pm 0.28^{a}$ & $77.14 \pm 0.09^{a}$ & $118.66 \pm 3.06^{\mathrm{a}}$ & $82.60 \pm 0.46^{b}$ & $26.96 \pm 0.27^{\mathrm{a}}$ & $0.99 \pm 0.01^{b}$ \\
\hline $\mathrm{CuM}$ & $44.62 \pm 0.08^{b}$ & $36.94 \pm 0.23^{b}$ & $67.12 \pm 2.19^{c}$ & $48.01 \pm 2.09^{c}$ & $14.22 \pm 0.85^{\mathrm{b}}$ & $1.04 \pm 0.03^{b}$ \\
\hline CuEO & n.a. & $13.69 \pm 2.05^{c}$ & $105.21 \pm 1.71^{b}$ & $87.71 \pm 0.97^{a}$ & n.a. & $40.33 \pm 3.62^{a}$ \\
\hline \multicolumn{7}{|c|}{ Clove Extracts } \\
\hline $\mathrm{ClH}$ & $394.48 \pm 1.37^{\mathrm{d}}$ & $727.19 \pm 1.00^{c}$ & $866.12 \pm 47.11^{c}$ & $1209.92 \pm 71.14^{b}$ & $3.64 \pm 0.30^{c}$ & $6.02 \pm 0.08^{b}$ \\
\hline ClD & $355.23 \pm 1.44^{\mathrm{e}}$ & $669.32 \pm 4.71^{\mathrm{d}}$ & $753.39 \pm 2.65^{\mathrm{d}}$ & $973.49 \pm 5.96^{c}$ & $4.09 \pm 0.79^{c}$ & $5.21 \pm 0.06^{b}$ \\
\hline ClMW & $488.45 \pm 0.38^{b}$ & $770.12 \pm 1.40^{b}$ & $978.08 \pm 21.03^{b}$ & $1027.41 \pm 12.79^{c}$ & $22.78 \pm 1.31^{\mathrm{a}}$ & $4.92 \pm 0.01^{b}$ \\
\hline $\mathrm{ClM}$ & $437.36 \pm 3.59^{c}$ & $722.91 \pm 1.91^{\mathrm{c}}$ & $778.93 \pm 8.46^{\mathrm{d}}$ & $876.30 \pm 13.24^{\mathrm{d}}$ & $14.71 \pm 0.33^{b}$ & $4.38 \pm 0.11^{\mathrm{b}}$ \\
\hline CIEO & $525.78 \pm 0.30^{a}$ & $936.44 \pm 0.17^{a}$ & $2848.28 \pm 13.89^{a}$ & $1927.98 \pm 18.80^{a}$ & $11.88 \pm 1.87^{\mathrm{b}}$ & $68.19 \pm 3.25^{a}$ \\
\hline \multicolumn{7}{|c|}{ Laurel Extracts } \\
\hline $\mathrm{LaH}$ & $2.08 \pm 0.16^{\mathrm{e}}$ & $11.40 \pm 0.64^{\mathrm{e}}$ & $28.58 \pm 4.44^{\mathrm{e}}$ & $14.11 \pm 2.89^{\mathrm{e}}$ & $14.50 \pm 0.63^{c}$ & $2.02 \pm 0.09^{b}$ \\
\hline LaD & $6.27 \pm 0.45^{\mathrm{d}}$ & $21.52 \pm 1.35^{\mathrm{d}}$ & $52.90 \pm 2.63^{\mathrm{d}}$ & $32.34 \pm 2.84^{\mathrm{d}}$ & $21.22 \pm 0.84^{b}$ & $2.07 \pm 0.10^{b}$ \\
\hline LaMW & $194.14 \pm 0.48^{\mathrm{a}}$ & $280.91 \pm 0.77^{\mathrm{b}}$ & $303.47 \pm 7.16^{b}$ & $196.49 \pm 2.92^{b}$ & $14.83 \pm 0.50^{c}$ & $2.03 \pm 0.02^{b}$ \\
\hline LaM & $113.12 \pm 1.56^{b}$ & $143.84 \pm 12.76^{c}$ & $143.40 \pm 1.03^{c}$ & $93.23 \pm 7.95^{c}$ & $16.32 \pm 0.35^{b c}$ & $1.99 \pm 0.09^{b}$ \\
\hline LaEO & $91.57 \pm 1.33^{c}$ & $507.33 \pm 6.15^{a}$ & $416.67 \pm 21.48^{a}$ & $435.97 \pm 4.23^{a}$ & $33.78 \pm 5.03^{a}$ & $49.10 \pm 2.53^{a}$ \\
\hline \multicolumn{7}{|c|}{ Black Pepper Extracts } \\
\hline BpH & $18.77 \pm 0.24^{d}$ & $41.41 \pm 1.67^{c}$ & $52.39 \pm 0.80^{c}$ & $68.19 \pm 0.31^{c}$ & $20.62 \pm 2.13^{b}$ & $1.35 \pm 0.03^{b}$ \\
\hline $\mathrm{BpD}$ & $19.56 \pm 0.59^{c}$ & $34.26 \pm 0.58^{d}$ & $48.96 \pm 4.87^{c}$ & $53.69 \pm 6.64^{d}$ & $10.94 \pm 0.26^{\mathrm{d}}$ & $0.98 \pm 0.02^{c}$ \\
\hline BpMW & $45.41 \pm 0.03^{\mathrm{a}}$ & $76.58 \pm 0.13^{a}$ & $106.38 \pm 0.45^{b}$ & $84.06 \pm 1.61^{b}$ & $30.51 \pm 0.11^{\mathrm{a}}$ & $1.09 \pm 0.00^{c}$ \\
\hline BpM & $32.41 \pm 0.07^{b}$ & $49.88 \pm 0.88^{b}$ & $51.22 \pm 1.64^{\mathrm{c}}$ & $68.27 \pm 3.19^{c}$ & n.a. & $0.95 \pm 0.02^{\mathrm{c}}$ \\
\hline BpEO & n.a. & $33.75 \pm 3.55^{\mathrm{d}}$ & $174.06 \pm 2.57^{\mathrm{a}}$ & $169.06 \pm 2.23^{a}$ & $15.72 \pm 0.59^{c}$ & $59.80 \pm 6.50^{\mathrm{a}}$ \\
\hline
\end{tabular}

Data are presented as mean \pm standard deviation (SD) of three determinations; different superscript letters within columns indicate significant differences in the tested extracts for the same species $(p<0.05)$. Abbreviations: ABTS-2,2'-azino-bis(3-ethylbenzothiazoline) 6-sulfonic acid; $\mathrm{BpD}$-black pepper dichloromethane extract; BpEO-black pepper essential oil; $\mathrm{BpH}$-black pepper hexane extract; BpM-black pepper methanol extract; BpMW—black pepper 50\% aqueous methanol extract; CiD—cinnamon dichloromethane extract; $\mathrm{CiEO}$ - cinnamon essential oil; $\mathrm{CiH}$ - cinnamon hexane extract; $\mathrm{CiM} —$ cinnamon methanol extract; $\mathrm{CiMW}$, cinnamon 50\% aqueous methanol extract; $\mathrm{ClD}$, clove dichloromethane extract; $\mathrm{ClEO}$, clove essential oil; $\mathrm{ClH}$ —clove hexane extract; $\mathrm{ClM}$-clove methanol extract; ClMW—clove $50 \%$ aqueous methanol extract; $\mathrm{CuD} —$ cumin dichloromethane extract; $\mathrm{CuEO} —$ cumin essential oil; $\mathrm{CuH}-$ cumin hexane extract; CuM - cumin methanol extract; CuMW—-cumin 50\% aqueous methanol extract; CUPRAC—cupric ion reducing antioxidant capacity; DPPH-1,1-diphenyl-2-picrylhydrazyl; EDTAE—EDTA equivalents; FRAP—ferric ion reducing antioxidant power; LaD—laurel dichloromethane extract; LaEO_laurel essential oil; LaH—laurel hexane extract; LaM-laurel methanol extract; LaMW-laurel 50\% aqueous methanol extract; MCA—-metal chelating activity; n.a.—not active; PBD—phosphomolybdenum assay; TE—Trolox equivalents.

To summarize, the spent plant material extracts of the studied spices exhibited significant antioxidant properties, with different degrees of activity. It is noteworthy to mention the remarkable antioxidant effects of cinnamon and clove extracts, as revealed by the radical scavenging capacity and reducing power assays (Table 5). In accordance with our study, Assefa et al. [73] highlighted the clove and cinnamon extracts among 39 common spices as notable sources of antioxidants able to prevent the deleterious effects induced by oxidative stress. As depicted in Figure 1, significant correlations between TPC and free radical scavenging activity, reducing power, and total antioxidant capacity were established $(r>0.8)$. Similarly, several studies have demonstrated a significant correlation between antioxidant properties of spices and their total amount of phenolic compounds $[47,73,79]$. No relevant correlation was found between TFC and the observed antioxidant effects $(r$ $<0.37)$. Therefore, we can assume that phenolic compounds are the main contributors to the overall antioxidant activity of investigated extracts. In addition, TPC and TFC did not 
correlate with metal-chelating activity, thus other constituents might be responsible for the chelation capacity of the spent spice materials.

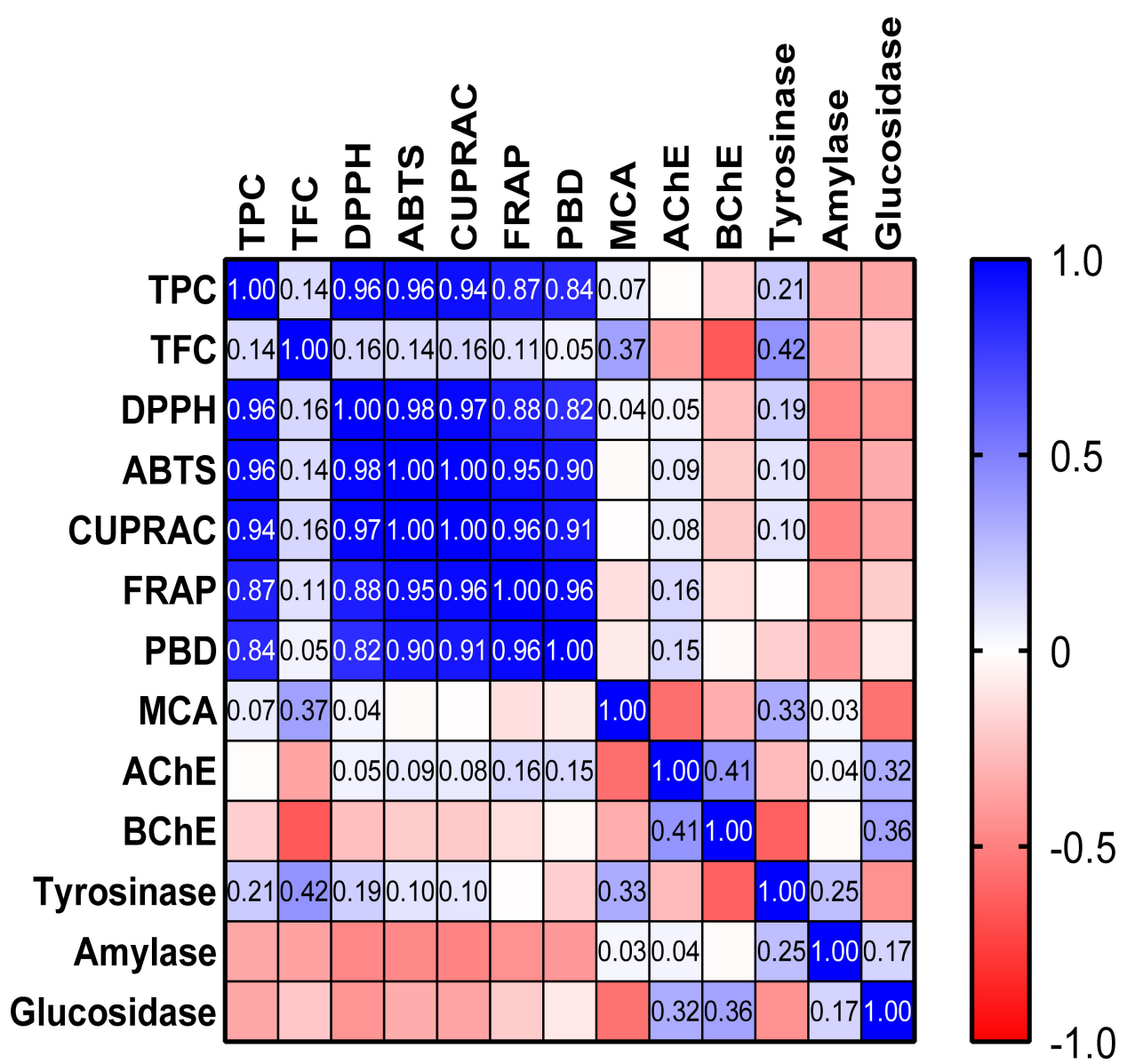

Figure 1. Pearson's correlation values $(r)$ in the performed biological activity assays; AChEacetylcholinesterase; $\mathrm{BChE}$ - butyrylcholinesterase; CUPRAC—cupric ion reducing antioxidant capacity; DPPH-1,1-diphenyl-2-picrylhydrazyl; FRAP-ferric ion reducing antioxidant power; MCA — metal chelating activity; PBD—phosphomolybdenum assay; TFC—-total flavonoid content; TPC—-total phenolic content.

\subsection{Anti-Enzymatic Activity of Extracts and Essential Oils Obtained from Different Spices}

For a better overview on the potential involvement of cinnamon, cumin, clove, laurel, and black pepper in the management of different chronic diseases, we next investigated the in vitro anti-enzymatic activity of the essential oils as well as of their spent spice material extracts (Table 6). As target enzymes, $\mathrm{AChE}, \mathrm{BChE}$, tyrosinase, amylase, and glucosidase were selected, since they are considered to be directly linked to the etiopathogeny of Alzheimer's disease, skin hyperpigmentation, or type II diabetes mellitus [56]. To the best of our knowledge, there are no previous comprehensive studies assessing the multienzymatic properties of these five spices. Similar to the antioxidant assays, we compared our results with literature data on unprocessed plant material.

The anti-AChE effects of cinnamon extracts varied between $1.14 \mathrm{mg}$ galanthamine equivalents (GALAE)/g (CiD) and $2.01 \mathrm{mg}$ GALAE/g [58], whereas slightly better antiBChE properties were noticed, especially for CiM extract (Table 6). Interestingly, CiEO was somehow active against $\mathrm{AChE}$, but inactive against $\mathrm{BChE}$, which could indicate a potential selectivity against the two enzymes. Previously, an ethanol cinnamon extract (200 $\mathrm{\mu g} / \mathrm{mL}$ ) was shown to exhibit $54.30 \%$ and $66.43 \%$ inhibition against AChE and BChE, respectively [80]. Regarding cumin extracts, the non-polar extracts $(\mathbf{C u H}$ and $\mathbf{C u D})$ showed the highest $\mathrm{AChE}$ and $\mathrm{BChE}$ inhibitory activities, with the other three samples being 
inactive, especially against BChE. Furthermore, $\mathrm{CuH}$ displayed the highest anti-AChE effects from all tested spices (2.95 mg GALAE/g). Mahnashi et al. [81] showed considerable inhibitory activities against $\mathrm{AChE}$ and $\mathrm{BChE}$ with $\mathrm{IC}_{50}$ values of 198 and $37 \mu \mathrm{g} / \mathrm{mL}$, respectively. The anti-cholinesterase activity of clove extracts varied in the following order: ClEO $>\mathrm{ClH}>\mathrm{ClD}>\mathrm{ClM}>\mathrm{ClMW}$, with the highest inhibitory capacity at 2.77 and 2.97 mg GALAE/g in AChE and BChE assays, respectively (Table 6). In a previous study, $\mathrm{IC}_{50}$ values of $49.73-61.50$ and $88.14-103.53 \mu \mathrm{g} / \mathrm{mL}$ were reported for a clove methanol extract and essential oil in AChE and BChE assays, respectively [82]. The non-polar LaH extract exhibited the highest anti-BChE effects from all analyzed spices (3.41 mg GALAE/g); in contrast, LaEO displayed very low BChE inhibitory properties (0.41 mg GALAE/g). With respect to the anti-AChE activity, the effects varied from 1.04 (LaMW) to $2.47 \mathrm{mg}$ GALAE/g (LaH). Ferreira et al. [83] showed that the laurel essential oil, aqueous, and ethanol extracts produced AChE inhibitions of $51.3 \% 19.9 \%$, and $48.4 \%$, respectively, at $0.5 \mathrm{mg} / \mathrm{mL}$; there was no information about their BChE inhibitory properties. Lastly, BpD exhibited the highest anti-AChE ability (2.55 mg GALAE/g), whereas the highest anti-BChE effects (2.46 mg GALAE/g) were noticed for BpMW. In a previous study, Luca et al. [56] showed that the $\mathrm{AChE}$ and $\mathrm{BChE}$ inhibitory activity of various pepper samples varied from 0 to 2.35 $\mathrm{mg}$ GALAE/g and 0.60 to $3.11 \mathrm{mg}$ GALAE/g, respectively.

When assessing tyrosinase inhibition (Table 6), it was noticed that the polar CiMW and CiM extracts clearly displayed the most potent effects (66.45 and $61.56 \mathrm{mg}$ kojic acid equivalents (KAE)/g, respectively), which were 2.5-3.6-fold higher than the remaining cinnamon samples. Previously, Tamfu et al. [80] showed that an ethanol cinnamon extract $(200 \mu \mathrm{g} / \mathrm{mL})$ exhibited a $45.37 \%$ inhibition against tyrosinase. Cumin extracts exerted a comparable anti-tyrosinase activity, with the highest effects also noticed in the polar extracts CuM (58.05 mg KAE/g) and CuMW (63.12 mg KAE/g). Mukherjee et al. [84] and Gholamhoseinian and Razmi [85] reported tyrosinase inhibitions of 52\% and $64.17 \%$ for methanol cumin extracts at 1.14 and $1 \mathrm{mg} / \mathrm{mL}$, respectively. The tyrosinase inhibitory properties of clove extracts varied between $20.79(\mathbf{C l H})$ and $59.23 \mathrm{mg} \mathrm{KAE} / \mathrm{g}(\mathbf{C l M W})$, with CIEO showing an inhibition of only $38.16 \mathrm{mg} \mathrm{KAE/g}$. The anti-tyrosinase abilities of clove have been scarcely reported; for instance, Ahmed et al. [86] compared the activity of different clove extracts; with respect to the $\mathrm{IC}_{50}$ values, the following order was observed: essential oil $(12.1 \mu \mathrm{g} / \mathrm{mL})>$ hexane extract $(17.4 \mu \mathrm{g} / \mathrm{mL})>$ methanol extract $(30.1 \mu \mathrm{g} / \mathrm{mL})$ $>$ ethanol extract $(65.3 \mu \mathrm{g} / \mathrm{mL})$. Within the series of laurel extracts, LaEO, LaM, and LaMW showed anti-tyrosinase effects to different extents (22.48-43.38 mg KAE/g), whereas the non-polar extracts were inactive. Deniz et al. [87] noticed that the $80 \%$ ethanol extracts of laurel exhibited a low tyrosinase inhibition $(34.09 \%$ at $666 \mu \mathrm{g} / \mathrm{mL})$. With respect to the black pepper extracts, it was observed that the non-polar extracts (BpH and $\mathbf{B p D})$ had the most potent anti-tyrosinase abilities; in contrast, BpEO was the weakest tyrosinase inhibitor (Table 6). Previously, it was reported that black pepper extracts were able to significantly down-regulate mushroom tyrosinase (monophenolase and diphenolase) as well as murine tyrosinase [56].

Regarding the amylase and glucosidase inhibition, the five spice extracts displayed weak inhibitory properties; generally, they exhibited slightly better anti-glucosidase effects than anti-amylase effects. From all tested samples, LaEO presented the most notable amylase inhibition (1.29 mg acarbose equivalents (ACAE)/g) followed by $\mathbf{B p H}$ and $\mathbf{B p D}$ (1.00 and $0.99 \mathrm{mg} \mathrm{ACAE/g,} \mathrm{respectively);} \mathrm{CiEO,} \mathrm{CuEO,} \mathrm{and} \mathrm{BpEO} \mathrm{were} \mathrm{inactive} \mathrm{against}$ the same enzyme. From all essential oils, only ClEO was able to inhibit glucosidase (1.00 mg ACAE/g); nonetheless, the spice residue extracts showed lower anti-glucosidase effects (max. 0.88-0.89 mg ACAE/g in CiH, CiD, ClM, and LaM) (Table 6). The modulation of the two anti-diabetic enzymes by different spices was found to be in agreement with our data; for example, several cinnamon aqueous extracts were shown to inhibit amylase, maltase, and sucrose, with $\mathrm{IC}_{50}$ values of $1.23-1.77,0.58-1.96$, and $0.42-2.96 \mathrm{mg} / \mathrm{mL}$, respectively [88], whereas a cumin ethanol extract displayed inhibitory effects against glucosidase of $45 \%$ at $100 \mu \mathrm{g} / \mathrm{mL}$ [89]. An 80\% aqueous acetone clove extract was reported 
to exhibit anti-glucoside and anti-amylase effects, with $\mathrm{IC}_{50}$ values of 145.07 and 497.27 $\mu \mathrm{g} / \mathrm{mL}$, respectively [90], whilst the clove essential oil displayed $\mathrm{IC}_{50}$ values of 71.94 and $88.89 \mu \mathrm{g} / \mathrm{mL}$ against the same two enzymes [91]. Moreover, a laurel extract exerted a $47.26 \%$ inhibition against glucosidase at $200 \mu \mathrm{g} / \mathrm{mL}$ [92], whereas different black pepper extracts showed weak anti-glucosidase effects of 0.84-1.22 mmol ACAE/g [56].

Overall, no significant correlations between the AChE, BChE, amylase, and glucosidase inhibitory activity of the investigated spices and their TPC and TFC were noticed. On the one hand, this can suggest that other categories of compounds might contribute to the observed effects; on the other hand, the tested spices exhibited modest anti-enzymatic activities, making the unveiling of the responsible biomolecules difficult. Nevertheless, the most promising anti-enzymatic effects were noticed with respect to tyrosinase; in addition, weak and moderate correlations between TPC $(r=0.21)$ and TFC $(r=0.42)$, respectively, and anti-tyrosinase activity were observed (Figure 1).

Table 6. Anti-enzymatic activity of different spice extracts and essential oils.

\begin{tabular}{|c|c|c|c|c|c|}
\hline Sample & AChE & BChE & Tyrosinase & Amylase & Glucosidase \\
\hline & \multicolumn{2}{|c|}{ (mg GALAE/g) } & (mg KAE/g) & \multicolumn{2}{|c|}{ (mmol ACAE/g) } \\
\hline \multicolumn{6}{|c|}{ Cinnamon Extracts } \\
\hline $\mathrm{CiH}$ & $1.70 \pm 0.02^{b}$ & $1.95 \pm 0.00^{b}$ & $18.24 \pm 4.89^{b}$ & $0.53 \pm 0.01^{\mathrm{a}}$ & $0.88 \pm 0.00^{a}$ \\
\hline CiD & $1.14 \pm 0.03^{c}$ & $1.87 \pm 0.07^{b}$ & $23.88 \pm 0.54^{b}$ & $0.41 \pm 0.02^{c}$ & $0.88 \pm 0.00^{\mathrm{a}}$ \\
\hline CiMW & $1.75 \pm 0.05^{b}$ & $0.45 \pm 0.05^{\mathrm{c}}$ & $66.45 \pm 0.32^{\mathrm{a}}$ & $0.41 \pm 0.02^{c}$ & n.a. \\
\hline CiM & $2.01 \pm 0.20^{\mathrm{a}}$ & $3.18 \pm 0.05^{\mathrm{a}}$ & $61.56 \pm 3.53^{a}$ & $0.45 \pm 0.02^{b}$ & $0.80 \pm 0.00^{b}$ \\
\hline CiEO & $1.77 \pm 0.17^{\mathrm{b}}$ & n.a. & $24.41 \pm 4.10^{b}$ & n.a. & n.a. \\
\hline \multicolumn{6}{|c|}{ Cumin Extracts } \\
\hline $\mathrm{CuH}$ & $2.95 \pm 0.01^{\mathrm{a}}$ & $2.57 \pm 0.02^{\mathrm{a}}$ & $26.31 \pm 2.63^{\mathrm{d}}$ & $0.31 \pm 0.03^{\mathrm{a}}$ & $0.82 \pm 0.02^{\mathrm{a}}$ \\
\hline CuD & $2.34 \pm 0.09^{b}$ & $2.11 \pm 0.05^{b}$ & $28.30 \pm 1.60^{c}$ & $0.33 \pm 0.02^{\mathrm{a}}$ & $0.84 \pm 0.00^{\mathrm{a}}$ \\
\hline CuMW & $1.04 \pm 0.04^{\mathrm{d}}$ & n.a. & $63.12 \pm 0.51^{a}$ & $0.30 \pm 0.00^{\mathrm{a}}$ & $0.45 \pm 0.01^{c}$ \\
\hline $\mathrm{CuM}$ & $1.53 \pm 0.07^{c}$ & n.a. & $58.05 \pm 2.65^{\mathrm{a}}$ & $0.31 \pm 0.02^{\mathrm{a}}$ & $0.77 \pm 0.01^{b}$ \\
\hline CuEO & $0.73 \pm 0.02 \mathrm{e}^{\mathrm{e}}$ & n.a. & $41.31 \pm 4.83^{b}$ & n.a. & n.a. \\
\hline \multicolumn{6}{|c|}{ Clove Extracts } \\
\hline $\mathrm{ClH}$ & $2.48 \pm 0.35^{\mathrm{ab}}$ & $2.45 \pm 0.22^{b}$ & $20.79 \pm 0.73^{c}$ & $0.32 \pm 0.03^{b}$ & $0.83 \pm 0.00^{c}$ \\
\hline ClD & $1.96 \pm 0.30^{b c}$ & $1.97 \pm 0.17^{c}$ & $22.51 \pm 0.63^{c}$ & $0.32 \pm 0.01^{\mathrm{b}}$ & $0.84 \pm 0.01^{\mathrm{c}}$ \\
\hline ClMW & $1.64 \pm 0.11^{b}$ & n.a. & $59.23 \pm 0.14^{\mathrm{a}}$ & $0.19 \pm 0.01^{\mathrm{c}}$ & n.a. \\
\hline $\mathrm{ClM}$ & $1.96 \pm 0.11^{b c}$ & $0.58 \pm 0.02^{\mathrm{d}}$ & $40.33 \pm 4.09^{b}$ & $0.30 \pm 0.02^{b}$ & $0.89 \pm 0.00^{b}$ \\
\hline CIEO & $2.77 \pm 0.18^{a}$ & $2.94 \pm 0.09^{a}$ & $38.16 \pm 5.16^{b}$ & $0.68 \pm 0.01^{\mathrm{a}}$ & $1.00 \pm 0.02^{\mathrm{a}}$ \\
\hline \multicolumn{6}{|c|}{ Laurel Extracts } \\
\hline LaH & $2.47 \pm 0.12^{a}$ & $3.41 \pm 0.63^{a}$ & n.a. & $0.55 \pm 0.00^{b}$ & $0.80 \pm 0.02^{b}$ \\
\hline LaD & $1.59 \pm 0.01^{b c}$ & $1.68 \pm 0.33^{b}$ & n.a. & $0.57 \pm 0.01^{\mathrm{b}}$ & $0.77 \pm 0.01^{\mathrm{c}}$ \\
\hline LaMW & $1.04 \pm 0.03^{\mathrm{d}}$ & $1.44 \pm 0.33^{b}$ & $43.38 \pm 1.53^{a}$ & $0.32 \pm 0.00^{c}$ & $0.89 \pm 0.01^{\mathrm{a}}$ \\
\hline LaM & $1.82 \pm 0.08^{b}$ & $1.66 \pm 0.05^{b}$ & $27.68 \pm 1.56^{b}$ & $0.45 \pm 0.01^{b c}$ & $0.83 \pm 0.01^{b}$ \\
\hline LaEO & $1.35 \pm 0.15^{\mathrm{e}}$ & $0.41 \pm 0.10^{c}$ & $22.48 \pm 0.59^{c}$ & $1.29 \pm 0.13^{\mathrm{a}}$ & n.a. \\
\hline \multicolumn{6}{|c|}{ Black Pepper Extracts } \\
\hline BpH & $1.48 \pm 0.03^{c}$ & n.a. & $76.86 \pm 1.29^{a}$ & $1.00 \pm 0.09^{\mathrm{a}}$ & $0.85 \pm 0.00^{\mathrm{a}}$ \\
\hline BpD & $2.55 \pm 0.03^{\mathrm{a}}$ & $1.24 \pm 0.32^{b}$ & $69.56 \pm 2.44^{b}$ & $0.99 \pm 0.02^{\mathrm{a}}$ & $0.76 \pm 0.02^{b}$ \\
\hline BpMW & $0.76 \pm 0.04^{\mathrm{d}}$ & $2.46 \pm 0.22^{a}$ & $49.31 \pm 1.12^{c}$ & $0.58 \pm 0.01^{\mathrm{c}}$ & $0.17 \pm 0.00^{c}$ \\
\hline BpM & $1.78 \pm 0.05^{b}$ & $1.26 \pm 0.02^{b}$ & $43.94 \pm 1.25^{\mathrm{d}}$ & $0.84 \pm 0.06^{\mathrm{b}}$ & $0.75 \pm 0.01^{b}$ \\
\hline BpEO & $2.43 \pm 0.10^{\mathrm{a}}$ & $2.16 \pm 0.03^{a}$ & $26.43 \pm 0.36^{\mathrm{e}}$ & n.a. & n.a. \\
\hline
\end{tabular}

Data are presented as mean \pm standard deviation (SD) of three determinations; different superscript letters within columns indicate significant differences in the tested extracts for the same species $(p<0.05)$. Abbreviations: ACAE—acarbose equivalents; $\mathrm{AChE}$ —acetylcholinesterase; $\mathrm{BChE}$ — butyrylcholinesterase; $\mathrm{BpD}$ —black pepper dichloromethane extract; $\mathrm{BpEO}$-black pepper essential oil; $\mathrm{BpH}$-black pepper hexane extract; $\mathrm{BpM}$-black pepper methanol extract; BpMW—-black pepper 50\% aqueous methanol extract; CiD—cinnamon dichloromethane extract; $\mathrm{CiEO}$ - cinnamon essential oil; $\mathrm{CiH}$ - cinnamon hexane extract; $\mathrm{CiM}$ - cinnamon methanol extract; CiMW—cinnamon 50\% aqueous methanol extract; $\mathrm{ClD}$ —clove dichloromethane extract; $\mathrm{ClEO}$ —clove essential oil; $\mathrm{ClH}$-clove hexane extract; $\mathrm{ClM}$ - clove methanol extract; $\mathrm{ClMW}$-clove 50\% aqueous methanol extract; $\mathrm{CuD} —$ cumin dichloromethane extract; $\mathrm{CuEO}$ — cumin essential oil; $\mathrm{CuH}$-cumin hexane extract; $\mathrm{CuM} —$ cumin methanol extract; CuMW—cumin 50\% aqueous methanol extract; GALAE—galanthamine equivalents; KAEkojic acid equivalants; LaD—laurel dichloromethane extract; LaEO—laurel essential oil; LaH-laurel hexane extract; LaM-laurel methanol extract; LaMW—-laurel 50\% aqueous methanol extract; n.a.—not active. 


\section{Material and Methods}

\subsection{Plant Materials}

Dried plant materials (cinnamon barks, cumin fruits, clove buds, laurel leaves, and black pepper fruits) were purchased from pharmacies and local markets and their botanical identity was confirmed by one of the authors (A.T.). Voucher specimens (Ci 1/2020, Cu 2/2020, Cl 3/2020, La 4/2020, Bp 5/2020) were deposited in the Department of Pharmacognosy, Faculty of Pharmacy, "Grigore T. Popa" University of Medicine and Pharmacy Iasi, Romania.

\subsection{Extraction}

\subsubsection{Essential Oil Isolation}

The powdered plant materials ( $50 \mathrm{~g}$ each) were subjected to hydrodistillation for $3 \mathrm{~h}$ in a Clevenger-type apparatus. EOs were dried over anhydrous sodium sulfate and stored in dark glass tubes at a temperature of $4{ }^{\circ} \mathrm{C}$ until further analysis.

\subsubsection{Preparation of Spent Plant Material Extracts}

The spent plant materials (after essential oil isolation) were dried at $40{ }^{\circ} \mathrm{C}(48 \mathrm{~h})$ and further extracted using solvents of different polarities (hexane, dichloromethane, methanol, and $50 \%$ aqueous methanol) by ultra-sonication ( 3 cycles of 30 min each, at room temperature). The obtained extracts were evaporated to dryness under vacuum (with the yields provided in Table 1 ) and kept at $-20^{\circ} \mathrm{C}$ until subsequent analysis.

\subsection{GC-MS and GC-FID Analysis}

An Agilent $6890 \mathrm{~N}$ gas chromatograph [93] coupled with a mass spectrometer (MS) detector (Agilent model 5975 inert XL) and a flame ionization detector (FID) was used to assess the qualitative and quantitative profile of essential oils isolated from investigated spices. TRB-5MS capillary columns ( $30 \mathrm{~m}$ length, $0.25 \mathrm{~mm}$ internal diameter, $0.25 \mu \mathrm{m}$ film thickness) were used for each detector. The analysis was conducted according to a previously described method [94]. Retention indices were calculated for the individual compounds using a standard mixture of $\mathrm{C} 8-\mathrm{C} 20 n$-alkanes. The compounds from the essential oils were identified by comparison of their mass spectra with those from the NIST 11 Mass Spectra Library, and their retention indices with literature data (NIST Chemistry WebBook; $[94,95])$. The relative percentages of individual compounds were obtained from the FID peak areas without using correction factors.

\subsection{LC-HRMS/MS Analysis}

The LC-HRMS/MS was performed on an Agilent 1200 HPLC system (Agilent Technologies, Palo Alto, CA, USA) equipped with a binary pump (G1312C), column thermostat (G1316A), auto-sampler (G1329B), and accurate-mass quadrupole-time-of-flight MS detector (G6530B). The separations were carried out on a Phenomenex Gemini C18 column $(2 \times$ $100 \mathrm{~mm}, 3 \mu \mathrm{m})$, with phase A (0.1\% formic acid in water) and phase $B(0.1 \%$ formic acid in acetonitrile); the mobile phase gradient was as follows: $10-60 \%$ B (0-45 $\mathrm{min})$ and $90 \% \mathrm{~B}$ (46-50 $\mathrm{min}$ ); flow rate $0.2 \mathrm{~mL} / \mathrm{min}$; injection volume $2 \mu \mathrm{L}$. The following MS parameters were set: electrospray ionization source (ESI); full-scan high-resolution accurate-mass acquisition mode; negative and positive ionization modes; $m / z$ range $50-1000 ; \mathrm{N}_{2}$ flow rate $12 \mathrm{~L} / \mathrm{min}$, vaporizer temperature $350^{\circ} \mathrm{C}$, nebulizer pressure $40 \mathrm{psi}$, capillary voltage $4000 \mathrm{~V}$, skimmer $65 \mathrm{~V}$, fragmentor $140 \mathrm{~V}$, and collision-induced dissociation (CID) energy $40 \mathrm{~V}$. Data acquisition and analysis were achieved with MassHunter Workstation Data Acquisition 8.0 and Qualitative Navigator 8.0, respectively. The assignment of the peaks observed in the base peak chromatograms (BPC) of the different spice extracts was performed by comparing the spectrometric data with previous literature data reporting on the LC-MS analysis of similar constituents or online databases (METLIN, KNApSacK, PubChem, NIST Chemistry WebBook). 


\subsection{TPC, TFC, Antioxidant and Anti-Enzymatic Assays}

TPC and TFC were determined according to previously described methods $[96,97]$ and expressed as mg GAE/g (TPC) and mg RE/g (TFC). DPPH, ABTS, CUPRAC, and FRAP were performed as in $[96,97]$, with the results presented as $\mathrm{mg}$ TE/g. MCA and PBD were carried out as described in [96,97], with the data provided as mg EDTAE/g (MCA) and mmol TE/g (PBD). AChE, BChE, tyrosinase, amylase, and glucosidase inhibition methods were detailed in $[96,97]$. The anti-enzymatic activities were expressed as mg GALAE/g in $\mathrm{AChE}$ and $\mathrm{BChE}$ assays, $\mathrm{mg} \mathrm{KAE/g} \mathrm{d.w.} \mathrm{in} \mathrm{tyrosinase} \mathrm{assay} \mathrm{and} \mathrm{mmol} \mathrm{ACAE/g} \mathrm{d.w.} \mathrm{in}$ amylase and glucosidase assays.

\subsection{Statistical Analysis}

All the experiments were performed in three replicates, with the results presented as mean \pm standard deviation (SD). One-way analysis of variance (ANOVA) with Turkey's post hoc test was conducted; $p<0.05$ was considered statistically significant. The correlation analysis between TPC, TFC, and biological activities was reported as Pearson's coefficients, calculated using R software (v. 3.6.2).

\section{Conclusions}

The GC-MS and GC-FID analyses of the essential oils obtained from five common spices pointed out several phytochemical markers: cinnamaldehyde in cinnamon; cuminaldehyde and safranal in cumin; eugenol in clove; eucalyptol in laurel; and $\alpha$-terpinene, limonene, $\beta$-caryophyllene, and $\beta$-pinene in black pepper. On the other hand, the LCHRMS/MS profiling of the spent plant materials extracted with different polarity solvents revealed a complex phytochemical composition of the same spices: organic acids, phenolic acids, proanthocyanidins, and oxygenated fatty acids in cinnamon; flavonoids (free aglycons or glycosides of luteolin and apigenin) in cumin; flavonoids (free aglycons or glycosides of quercetin, isorhamnetin, luteolin, chrysoeriol, cirsiliol, cirsimaritin) and hydrolysable tannins in clove; proanthocyanidins and flavonoids (free aglycons and glycosides of quercetin, isorhamnetin and kaempferol) in laurel; and piperamides (piperine, piperlonguminine, pellitorine, pipernonaline, retrofractamide $\mathrm{B}$, guineensine and $\mathrm{N}$-isobutyl-dodecadienamide) in black pepper.

The comparative assessment of the antioxidant potential of the essential oils and spent spice material extracts indicated a very strong activity for all samples, as depicted from the significantly high values obtained in radical scavenging (ABTS, DPPH), metal chelating (MCA), reducing (CUPRAC, FRAP), and PBD tests. Interestingly, significant correlations between TPC and antioxidant activity of spent extracts were observed, with no relevant correlations between their TFC and the antioxidant effects. Lastly, the anti-enzymatic assays unveiled that the investigated spices exhibited a mild modulation of several key enzymes (cholinesterases, tyrosinase, glucosidase, and amylase) targeted in the management of chronic diseases, such as Alzheimer's disease, type 2 diabetes mellitus, or skin disorders.

Overall, our study shows that, not only the volatile fractions of common spices, such as cinnamon, cumin, clove, laurel, and black pepper, but also their spent plant materials remained after hydrodistillation, and often discarded by the essential oil industry, can be further considered as rich sources of exploitable bioactive molecules endowed with antioxidant and multi-enzymatic inhibitory activities.

Author Contributions: Conceptualization, A.T. and S.V.L.; methodology, A.T., G.Z., M.B. and S.V.L.; software, A.T., G.Z., M.B. and S.V.L.; validation, A.T. and S.V.L.; formal analysis, A.T., G.Z. and S.V.L.; investigation A.T., G.Z. and S.V.L.; resources, A.T., G.Z., K.S.-W. and S.V.L.; data curation, S.V.L.; writing-original draft preparation, A.T. and S.V.L.; writing—review and editing, M.B., G.Z. and K.S.-W.; visualization, A.T. and S.V.L.; supervision, A.T. and S.V.L.; project administration, A.T. and S.V.L.; funding acquisition, A.T. All authors have read and agreed to the published version of the manuscript. 
Funding: This work was supported by a grant from the Romanian Ministry of Education and Research, CNCS - UEFISCDI, project number PN-III-P1-1.1-TE-2019-1894, within PNCDI III. K.S.W. acknowledges the financial support of the Medical University of Lublin, project DS 28.

Institutional Review Board Statement: Not applicable.

Informed Consent Statement: Not applicable.

Data Availability Statement: Not applicable.

Conflicts of Interest: The authors declare no conflict of interest. The funders had no role in the design of the study; in the collection, analyses, or interpretation of data; in the writing of the manuscript, or in the decision to publish the results.

\section{References}

1. Embuscado, M.E. Spices and herbs: Natural sources of antioxidants-A mini review. J. Funct. Foods 2015, 18, 811-819. [CrossRef]

2. Shahidi, F.; Ambigaipalan, P. Phenolics and polyphenolics in foods, beverages and spices: Antioxidant activity and health effects-A review. J. Funct. Foods 2015, 18, 820-897. [CrossRef]

3. Srinivasan, K. Black pepper and its pungent principle-piperine: A review of diverse physiological effects. Crit. Rev. Food Sci. Nutr. 2007, 47, 735-748. [CrossRef] [PubMed]

4. Peter, K.V.; Shylaja, M.R. Introduction to herbs and spices: Definitions, trade and applications. In Handbook of Herbs and Spices; Peter, K.V., Ed.; Woodhead Publishing: Cambridge, UK, 2012; Volume 1, pp. 1-25.

5. Rao, P.V.; Gan, S.H. Cinnamon: A multifaceted medicinal plant. Evid. Based Complemen. Altern. Med. 2014, $2014,642942$. [CrossRef]

6. Ranasinghe, P.; Pigera, S.; Premakumara, G.S.; Galappaththy, P.; Constantine, G.R.; Katulanda, P. Medicinal properties of 'true'cinnamon (Cinnamomum zeylanicum): A systematic review. BMC Complemen. Altern. Med. 2013, 13, 275. [CrossRef]

7. Wang, J.; Su, B.; Jiang, H.; Cui, N.; Yu, Z.; Yang, Y.; Sun, Y. Traditional uses, phytochemistry and pharmacological activities of the genus Cinnamomum (Lauraceae): A review. Fitoterapia 2020, 146, 104675. [CrossRef]

8. Kumar, S.; Kumari, R.; Mishra, S. Pharmacological properties and their medicinal uses of Cinnamomum: A review. J. Pharm. Pharmacol. 2019, 71, 1735-1761. [CrossRef]

9. Barnes, J.; Anderson, L.A.; Phillipson, J.D. Herbal Medicines, 3rd ed.; Pharmaceutical Press: London, UK, 2007 ; pp. 162-164.

10. Singh, N.; Yadav, S.S.; Kumar, S.; Narashiman, B. A review on traditional uses, phytochemistry, pharmacology, and clinical research of dietary spice Cuminum cyminum L. Phytother. Res. 2021, 35, 5007-5030. [CrossRef]

11. Idowu, S.; Adekoya, A.E.; Igiehon, O.O.; Idowu, A.T. Clove (Syzygium aromaticum) spices: A review on their bioactivities, current use, and potential application in dairy products. J. Food Meas. Charact. 2021, 15, 1-17. [CrossRef]

12. Cortés-Rojas, D.F.; de Souza, C.R.F.; Oliveira, W.P. Clove (Syzygium aromaticum): A precious spice. Asian Pac. J. Trop. Biomed. 2014, 4, 90-96. [CrossRef]

13. Aung, E.E.; Kristanti, A.N.; Aminah, N.S.; Takaya, Y.; Ramadhan, R. Plant description, phytochemical constituents and bioactivities of Syzygium genus: A review. Open Chem. 2020, 18, 1256-1281. [CrossRef]

14. Haro-González, J.N.; Castillo-Herrera, G.A.; Martínez-Velázquez, M.; Espinosa-Andrews, H. Clove essential oil (Syzygium aromaticum L. Myrtaceae): Extraction, chemical composition, food applications, and essential bioactivity for human health. Molecules 2021, 26, 6387. [CrossRef]

15. Heinrich, M.; Williamson, E.M.; Gibbons, S.; Barnes, J.; Prieto-Garcia, J. Fundamentals of Pharmacognosy and Phytotherapy, 2nd ed.; Elsevier: Edinbourg, UK, 2012; pp. 294-295.

16. El-Saber Batiha, G.; Alkazmi, L.M.; Wasef, L.G.; Beshbishy, A.M.; Nadwa, E.H.; Rashwan, E.K. Syzygium aromaticum L. (Myrtaceae): Traditional uses, bioactive chemical constituents, pharmacological and toxicological activities. Biomolecules 2020, 10, 202. [CrossRef]

17. Charles, D.J. Antioxidant Properties of Spices, Herbs and Other Sources; Springer Science Business Media: New York, NY, USA, 2013; pp. 265-271.

18. Singh, R.P.; Gangadharappa, H.; Mruthunjaya, K. Cuminum cyminum-A popular spice: An updated review. Pharmacog. J. 2017, 9, 292-301. [CrossRef]

19. Tavakoli-Rouzbehani, O.M.; Faghfouri, A.H.; Anbari, M.; Papi, S.; Shojaei, F.S.; Ghaffari, M.; Alizadeh, M. The effects of Cuminum cyminum on glycemic parameters: A systematic review and meta-analysis of controlled clinical trials. J. Ethnopharmacol. 2021, 281, 114510. [CrossRef]

20. Hadi, A.; Mohammadi, H.; Hadi, Z.; Roshanravan, N.; Kafeshani, M. Cumin (Cuminum cyminum L.) is a safe approach for management of lipid parameters: A systematic review and meta-analysis of randomized controlled trials. Phytother. Res. 2018, 32, 2146-2154. [CrossRef]

21. Chahal, K.; Kaur, M.; Bhardwaj, U.; Singla, N.; Kaur, A.; Kaur, M.; Bhardwaj, U.; Singla, N.; Kaur, A. A review on chemistry and biological activities of Laurus nobilis L. essential oil. J. Pharmacogn. Phytochem. 2017, 6, 1153-1161.

22. De La Torre Torres, J.E.; Gassara, F.; Kouassi, A.P.; Brar, S.K.; Belkacemi, K. Spice use in food: Properties and benefits. Crit. Rev. Food Sci. Nutr. 2017, 57, 1078-1088. 
23. Bianchi, A. The Mediterranean aromatic plants and their culinary use. Nat. Prod. Res. 2015, 29, 201-206. [CrossRef]

24. Alejo-Armijo, A.; Altarejos, J.; Salido, S. Phytochemicals and biological activities of Laurel tree (Laurus nobilis). Nat. Prod. Comm. 2017, 12, 1934578X1701200519. [CrossRef]

25. Dall'Acqua, S.; Cervellati, R.; Speroni, E.; Costa, S.; Guerra, M.C.; Stella, L.; Greco, E.; Innocenti, G. Phytochemical composition and antioxidant activity of Laurus nobilis L. leaf infusion. J. Med. Food 2009, 12, 869-876. [CrossRef]

26. Sharma, A.; Singh, J.; Kumar, S. Bay leaves. In Handbook of Herbs and Spices; Peter, K.V., Ed.; Woodhead Publishing: Cambridge, UK, 2012; Volume 1, pp. 73-85.

27. Riabov, P.A.; Micić, D.; Božović, R.B.; Jovanović, D.V.; Tomić, A.; Šovljanski, O.; Filip, S.; Tosti, T.; Ostojić, S.; Blagojević, S. The chemical, biological and thermal characteristics and gastronomical perspectives of Laurus nobilis essential oil from different geographical origin. Ind. Crops Prod. 2020, 151, 112498. [CrossRef]

28. Leja, K.B.; Czaczyk, K. The industrial potential of herbs and spices? A mini review. Acta Sci. Pol. Technol. Aliment. 2016, 15, 353-365. [CrossRef]

29. Salehi, B.; Zakaria, Z.A.; Gyawali, R.; Ibrahim, S.A.; Rajkovic, J.; Shinwari, Z.K.; Khan, T.; Sharifi-Rad, J.; Ozleyen, A.; Turkdonmez, E. Piper species: A comprehensive review on their phytochemistry, biological activities and applications. Molecules 2019, $24,1364$. [CrossRef]

30. Meghwal, M.; Goswami, T. Piper nigrum and piperine: An update. Phytother. Res. 2013, 27, 1121-1130. [CrossRef]

31. Takooree, H.; Aumeeruddy, M.Z.; Rengasamy, K.R.; Venugopala, K.N.; Jeewon, R.; Zengin, G.; Mahomoodally, M.F. A systematic review on black pepper (Piper nigrum L.): From folk uses to pharmacological applications. Crit. Rev. Food Sci. Nutr. 2019, 59, S210-S243. [CrossRef]

32. Ashokkumar, K.; Murugan, M.; Dhanya, M.; Pandian, A.; Warkentin, T.D. Phytochemistry and therapeutic potential of black pepper [Piper nigrum (L.)] essential oil and piperine: A review. Clin. Phytosci. 2021, 7, 52. [CrossRef]

33. Schmidt, E. Production of Essential Oils. In Handbook of Essential Oils: Science, Technology, and Applications; Can Baser, K.H. Buchbauer, G., Eds.; CRC Press: Boca Raton, FL, USA, 2010; pp. 83-120.

34. Greff, B.; Lakatos, E.; Szigeti, J.; Varga, L. Co-composting with herbal wastes: Potential effects of essential oil residues on microbial pathogens during composting. Crit. Rev. Environ. Sci. Technol. 2021, 51, 457-511. [CrossRef]

35. McGaw, D.R.; Maharaj, S. Supply chain evaluation for the plant extracts industry in the Eastern Caribbean. West Indian J. Eng. 2021, 43, 42-53.

36. Waweru, E.J.; Pogrebnaya, T.; Kivevele, T.T. Effect of antioxidants extracted from clove wastes and babul tree barks on the oxidation stability of biodiesel made from water hyacinth of Lake Victoria origin. Waste Biomass Valoris. 2020, 11, 5749-5758. [CrossRef]

37. Sijabat, P.S.; Siregar, Y. Study of distillation waste by clove for alternative fuel power plant: A review. In Proceedings of the IOP Conference Series Materials Science and Engineering, Medan, Indonesia, 28 September 2020; p. 012081.

38. Gao, Y.; Ozel, M.Z.; Dugmore, T.; Sulaeman, A.; Matharu, A.S. A biorefinery strategy for spent industrial ginger waste. J. Hazard. Mater. 2021, 401, 123400. [CrossRef]

39. Prabhu, G.R.D.; Kiran, C.R.; Sundaresan, A.; Mony, R.S.; Venugopalan, V. Process development studies for recovery of bio active isolates from spent black pepper generated from ayurvedic industry. Ind. Crops Prod. 2015, 66, 144-149. [CrossRef]

40. Milan, K.M.; Dholakia, H.; Tiku, P.K.; Vishveshwaraiah, P. Enhancement of digestive enzymatic activity by cumin (Cuminum cyminum L.) and role of spent cumin as a bionutrient. Food Chem. 2008, 110, 678-683. [CrossRef]

41. Sánchez-Vioque, R.; Polissiou, M.; Astraka, K.; De Los Mozos-Pascual, M.; Tarantilis, P.; Herraiz-Peñalver, D.; Santana-Méridas, O. Polyphenol composition and antioxidant and metal chelating activities of the solid residues from the essential oil industry. Ind. Crops Prod. 2013, 49, 150-159. [CrossRef]

42. Cid-Pérez, T.S.; Ávila-Sosa, R.; Ochoa-Velasco, C.E.; Rivera-Chavira, B.E.; Nevárez-Moorillón, G.V. Antioxidant and antimicrobial activity of Mexican oregano (Poliomintha longiflora) essential oil, hydrosol and extracts from waste solid residues. Plants 2019, 8 , 22. [CrossRef]

43. Moghaddam, M.; Miran, S.N.K.; Pirbalouti, A.G.; Mehdizadeh, L.; Ghaderi, Y. Variation in essential oil composition and antioxidant activity of cumin (Cuminum cyminum L.) fruits during stages of maturity. Ind. Crops Prod. 2015, 70, 163-169. [CrossRef]

44. Trifan, A.; Aprotosoaie, A.C.; Şpac, A.; Hăncianu, M.; Miron, A.; Stănescu, U. Contributions to the chemical study of the essential oil isolated from coriander (Omagiu cultivar) fruits. Farmacia 2012, 60, 177-183.

45. Jeena, K.; Liju, V.B.; Umadevi, N.; Kuttan, R. Antioxidant, anti-inflammatory and antinociceptive properties of black pepper essential oil (Piper nigrum Linn). J. Essent. Oil-Bear. Plants 2014, 17, 1-12. [CrossRef]

46. Trifan, A.; Zengin, G.; Sinan, K.I.; Wolfram, E.; Skalicka-Woźniak, K.; Luca, S.V. LC-HRMS/MS phytochemical profiling of Symphytum officinale L. and Anchusa ochroleuca M. Bieb. (Boraginaceae): Unveiling their multi-biological potential via an integrated approach. J. Pharm. Biomed. Anal. 2021, 204, 114283. [CrossRef]

47. Vallverdú-Queralt, A.; Regueiro, J.; Martínez-Huélamo, M.; Alvarenga, J.F.R.; Leal, L.N.; Lamuela-Raventos, R.M. A comprehensive study on the phenolic profile of widely used culinary herbs and spices: Rosemary, thyme, oregano, cinnamon, cumin and bay. Food Chem. 2014, 154, 299-307. [CrossRef]

48. Ali, A.; Wu, H.; Ponnampalam, E.N.; Cottrell, J.J.; Dunshea, F.R.; Suleria, H.A. Comprehensive profiling of most widely used spices for their phenolic compounds through LC-ESI-QTOF-MS ${ }^{2}$ and their antioxidant potential. Antioxidants 2021, $10,721$. [CrossRef] 
49. Vu, T.P.D.; Khong, T.Q.; Nguyen, T.M.N.; Kim, Y.H.; Kang, J.S. Phytochemical profile of Syzygium formosum (Wall.) Masam leaves using HPLC-PDA-MS/MS and a simple HPLC-ELSD method for quality control. J. Pharm. Biomed. Anal. 2019, 168, 1-12.

50. Araujo, N.M.P.; Arruda, H.S.; Dos Santos, F.N.; de Morais, D.R.; Pereira, G.A.; Pastore, G.M. LC-MS/MS screening and identification of bioactive compounds in leaves, pulp and seed from Eugenia calycina Cambess. Food Res. Int. 2020, $137,109556$. [CrossRef]

51. Rummun, N.; Serag, A.; Rondeau, P.; Ramsaha, S.; Bourdon, E.; Bahorun, T.; Farag, M.A.; Neergheen, V.S. Antiproliferative activity of Syzygium coriaceum, an endemic plant of Mauritius, with its UPLC-MS metabolite fingerprint: A mechanistic study. PLoS ONE 2021, 16, e0252276. [CrossRef]

52. Pacifico, S.; Gallicchio, M.; Lorenz, P.; Duckstein, S.M.; Potenza, N.; Galasso, S.; Marciano, S.; Fiorentino, A.; Stintzing, F.C.; Monaco, P. Neuroprotective potential of Laurus nobilis antioxidant polyphenol-enriched leaf extracts. Chem. Res. Toxicol. 2014, 27, 611-626. [CrossRef]

53. Bourebaba, N.; Kornicka-Garbowska, K.; Marycz, K.; Bourebaba, L.; Kowalczuk, A. Laurus nobilis ethanolic extract attenuates hyperglycemia and hyperinsulinemia-induced insulin resistance in HepG2 cell line through the reduction of oxidative stress and improvement of mitochondrial biogenesis-Possible implication in pharmacotherapy. Mitochondrion 2021, 59, 190-213. [CrossRef]

54. Fiorini, C.; David, B.; Fourasté, I.; Vercauteren, J. Acylated kaempferol glycosides from Laurus nobilis leaves. Phytochemistry 1998, 47, 821-824. [CrossRef]

55. Luca, S.V.; Minceva, M.; Gertsch, J.; Skalicka-Woźniak, K. LC-HRMS/MS-based phytochemical profiling of Piper spices: Global association of piperamides with endocannabinoid system modulation. Food Res. Int. 2021, 141, 110123. [CrossRef]

56. Luca, S.V.; Gaweł-Bęben, K.; Strzępek-Gomółka, M.; Czech, K.; Trifan, A.; Zengin, G.; Korona-Glowniak, I.; Minceva, M.; Gertsch, J.; Skalicka-Woźniak, K. Insights into the phytochemical and multifunctional biological profile of spices from the genus Piper. Antioxidants 2021, 10, 1642. [CrossRef]

57. Da Luz, S.F.; Yamaguchi, L.F.; Kato, M.J.; de Lemos, O.F.; Xavier, L.P.; Maia, J.G.S.; Ramos, A.D.R.; Setzer, W.N.; da Silva, J.K.D.R. Secondary metabolic profiles of two cultivars of Piper nigrum (Black Pepper) resulting from infection by Fusarium solani F. sp. piperis. Int. J. Mol. Sci. 2017, 18, 2434. [CrossRef]

58. Aćimović, M. Nutraceutical potential of Apiaceae. In Bioactive Molecules in Food; Reference Series in Phytochemistry RSP; Springer: New York, NY, USA, 2019; pp. 1311-1341.

59. Dudonne, S.; Vitrac, X.; Coutiere, P.; Woillez, M.; Mérillon, J.-M. Comparative study of antioxidant properties and total phenolic content of 30 plant extracts of industrial interest using DPPH, ABTS, FRAP, SOD, and ORAC assays. J. Agric. Food Chem. 2009, 57, 1768-1774. [CrossRef] [PubMed]

60. Su, L.; Yin, J.-J.; Charles, D.; Zhou, K.; Moore, J.; Yu, L.L. Total phenolic contents, chelating capacities, and radical-scavenging properties of black peppercorn, nutmeg, rosehip, cinnamon and oregano leaf. Food Chem. 2007, 100, 990-997. [CrossRef]

61. Gupta, D. Comparative analysis of spices for their phenolic content, flavonoid content and antioxidant capacity. Am. Int. J. Res. Form. Appl. Nat. Sci. 2013, 4, 38-42.

62. Rebey, I.B.; Zakhama, N.; Karoui, I.J.; Marzouk, B. Polyphenol composition and antioxidant activity of cumin (Cuminum cyminum L.) seed extract under drought. J. Food Sci. 2012, 77, C734-C739. [CrossRef]

63. El-Maati, M.F.A.; Mahgoub, S.A.; Labib, S.M.; Al-Gaby, A.M.; Ramadan, M.F. Phenolic extracts of clove (Syzygium aromaticum) with novel antioxidant and antibacterial activities. Eur. J. Integr. Med. 2016, 8, 494-504. [CrossRef]

64. Dobroslavić, E.; Elez Garofulić, I.; Zorić, Z.; Pedisić, S.; Dragović-Uzelac, V. Polyphenolic characterization and antioxidant capacity of Laurus nobilis L. leaf extracts obtained by green and conventional extraction techniques. Processes 2021, 9, 1840. [CrossRef]

65. Rincon, E.; Balu, A.M.; Luque, R.; Serrano, L. Mechanochemical extraction of antioxidant phenolic compounds from Mediterranean and medicinal Laurus nobilis: A comparative study with other traditional and green novel techniques. Ind. Crops Prod. 2019, 141, 111805. [CrossRef]

66. Zarai, Z.; Boujelbene, E.; Salem, N.B.; Gargouri, Y.; Sayari, A. Antioxidant and antimicrobial activities of various solvent extracts, piperine and piperic acid from Piper nigrum. LWT Food Sci. Technol. 2013, 50, 634-641. [CrossRef]

67. Gupta, K.; Testa, H.; Greenwood, T.; Kostek, M.; Haushalter, K.; Kris-Etherton, P.M.; Petersen, K.S. The effect of herbs and spices on risk factors for cardiometabolic diseases: A review of human clinical trials. Nutr. Rev. 2021. [CrossRef]

68. Saranya, B.; Sulfikarali, T.; Chindhu, S.; Muneeb, A.; Leela, N.; Zachariah, T. Turmeric and cinnamon dominate in antioxidant potential among four major spices. J. Spices Aromat. Crops. 2017, 26, 27-32. [CrossRef]

69. El Ghallab, Y.; Al Jahid, A.; Eddine, J.J.; Said, A.A.H.; Zarayby, L.; Derfoufi, S. Syzygium aromaticum L.: Phytochemical investigation and comparison of the scavenging activity of essential oil, extracts and eugenol. Adv. Tradit. Med. 2020, 20, 153-158. [CrossRef]

70. Speroni, E.; Cervellati, R.; Dall'Acqua, S.; Guerra, M.C.; Greco, E.; Govoni, P.; Innocenti, G. Gastroprotective effect and antioxidant properties of different Laurus nobilis L. leaf extracts. J. Med. Food 2011, 14, 499-504. [CrossRef]

71. Einafshar, S.; Poorazrang, H.; Farhoosh, R.; Seiedi, S.M. Antioxidant activity of the essential oil and methanolic extract of cumin seed (Cuminum cyminum). Eur. J. Lipid Sci. Technol. 2012, 114, 168-174. [CrossRef]

72. Carlsen, M.H.; Halvorsen, B.L.; Holte, K.; Bøhn, S.K.; Dragland, S.; Sampson, L.; Willey, C.; Senoo, H.; Umezono, Y.; Sanada, C. The total antioxidant content of more than 3100 foods, beverages, spices, herbs and supplements used worldwide. Nutr. J. 2010, 9 , 3. [CrossRef]

73. Assefa, A.D.; Keum, Y.-S.; Saini, R.K. A comprehensive study of polyphenols contents and antioxidant potential of 39 widely used spices and food condiments. J. Food Meas. Charact. 2018, 12, 1548-1555. [CrossRef] 
74. Rebey, I.B.; Jabri-Karoui, I.; Hamrouni-Sellami, I.; Bourgou, S.; Limam, F.; Marzouk, B. Effect of drought on the biochemical composition and antioxidant activities of cumin (Cuminum cyminum L.) seeds. Ind. Crops Prod. 2012, 36, 238-245. [CrossRef]

75. Gülçin, İ.; Şat, İ.G.; Beydemir, Ş.; Elmastaş, M.; Küfrevioğlu, Ö.İ. Comparison of antioxidant activity of clove (Eugenia caryophylata Thunb) buds and lavender (Lavandula stoechas L.). Food Chem. 2004, 87, 393-400. [CrossRef]

76. Wijewardhana, U.; Gunathilaka, U.; Navaratne, S. Determination of total phenolic content, radical scavenging activity and total antioxidant capacity of cinnamon bark, black cumin seeds and garlic. Int. Res. J. Adv. Eng. Sci. 2019, 4, 55-57.

77. Albayrak, S.; Aksoy, A.; Sagdic, O.; Albayrak, S. Antioxidant and antimicrobial activities of different extracts of some medicinal herbs consumed as tea and spices in Turkey. J. Food Biochem. 2012, 36, 547-554. [CrossRef]

78. Al Juhaimi, F.; Ghafoor, K. Extraction optimization and in vitro antioxidant properties of phenolic compounds from cumin (Cuminum cyminum 1.) seed. Int. Food Res. J. 2013, 20, 1669-1675.

79. Lu, M.; Yuan, B.; Zeng, M.; Chen, J. Antioxidant capacity and major phenolic compounds of spices commonly consumed in China. Food Res. Int. 2011, 44, 530-536. [CrossRef]

80. Tamfu, A.N.; Kucukaydin, S.; Ceylan, O.; Sarac, N.; Duru, M.E. Phenolic composition, enzyme inhibitory and anti-quorum sensing activities of cinnamon (Cinnamomum zeylanicum Blume) and basil (Ocimum basilicum Linn). Chem. Africa 2021, 4, 759-767. [CrossRef]

81. Mahnashi, M.H.; Alyami, B.A.; Alqahtani, Y.S.; Alqarni, A.O.; Jan, M.S.; Ayaz, M.; Ullah, F.; Shahid, M.; Rashid, U.; Sadiq, A. Neuroprotective potentials of selected natural edible oils using enzyme inhibitory, kinetic and simulation approaches. BMC Complement. Med. Ther. 2021, 21, 248. [CrossRef] [PubMed]

82. Dalai, M.K.; Bhadra, S.; Chaudhary, S.K.; Bandyopadhyay, A.; Mukherjee, P.K. Anti-cholinesterase activity of the standardized extract of Syzygium aromaticum L. Pharmacogn. Mag. 2014, 10, S276-S282. [PubMed]

83. Ferreira, A.; Proença, C.; Serralheiro, M.; Araujo, M. The in vitro screening for acetylcholinesterase inhibition and antioxidant activity of medicinal plants from Portugal. J. Ethnopharmacol. 2006, 108, 31-37. [CrossRef] [PubMed]

84. Mukherjee, P.; Badami, S.; Wahile, A.; Rajan, S.; Suresh, B. Evaluation of tyrosinase inhibitory activity of some Indian spices. J. Nat. Remedies 2001, 1, 125-129.

85. Gholamhoseinian, A.; Razmi, Z. Screening the methanolic extracts of some plants for tyrosinase inhibitory activity. Toxicol. Environ. Chem. 2012, 94, 310-318. [CrossRef]

86. Ahmed, W. Monitoring antioxidant and antityrosinase activity of clove aromatic flower buds. J. Med. Plants Stud. 2016, 4, 163-169.

87. Erdogan Orhan, I.; Karahisar, E.; Tugay, O.; Senol Deniz, F.S.; Skalicka-Wozniak, K.; Luca, S.V.; Sahin, M. Metabolite profiling by hyphenated liquid chromatographic mass spectrometric technique (HPLC-DAD-ESI-Q-TOF-MS/MS) and neurobiological potential of Haplophyllum sahinii and H. vulcanicum extracts. Chem. Biodivers. 2019, 16, e1900333.

88. Adisakwattana, S.; Lerdsuwankij, O.; Poputtachai, U.; Minipun, A.; Suparpprom, C. Inhibitory activity of cinnamon bark species and their combination effect with acarbose against intestinal $\alpha$-glucosidase and pancreatic $\alpha$-amylase. Plant Foods Hum. Nutr. 2011, 66, 143-148. [CrossRef]

89. Srivsatava, R.; Srivastava, S.P.; Jaiswal, N.; Mishra, A.; Maurya, R.; Srivastava, A.K. Antidiabetic and antidyslipidemic activities of Cuminum cyminum L. in validated animal models. Med. Chem. Res. 2011, 20, 1656-1666. [CrossRef]

90. Adefegha, S.A.; Oboh, G. In vitro inhibition activity of polyphenol-rich extracts from Syzygium aromaticum (L.) Merr. \& Perry (clove) buds against carbohydrate hydrolyzing enzymes linked to type 2 diabetes and Fe2+-induced lipid peroxidation in rat pancreas. Asian Pac. J. Trop. Biomed. 2012, 2, 774-781.

91. Oboh, G.; Akinbola, I.A.; Ademosun, A.O.; Sanni, D.M.; Odubanjo, O.V.; Olasehinde, T.A.; Oyeleye, S.I. Essential oil from clove bud (Eugenia aromatica Kuntze) inhibit key enzymes relevant to the management of type-2 diabetes and some pro-oxidant induced lipid peroxidation in rats pancreas in vitro. J. Oleo Sci. 2015, 64, 775-782. [CrossRef]

92. Indrianingsih, A.W.; Tachibana, S.; Itoh, K. In vitro evaluation of antioxidant and $\alpha$-glucosidase inhibitory assay of several tropical and subtropical plants. Proc. Environ. Sci. 2015, 28, 639-648. [CrossRef]

93. Elkiran, O.; Akbaba, E.; Bagci, E. Constituents of essential oils from leaves and seeds of Laurus nobilis L.: A Chemotaxonomic approach. Bangladesh J. Bot. 2018, 47, 893-901. [CrossRef]

94. Trifan, A.; Luca, S.V.; Bostănaru, A.-C.; Brebu, M.; Jităreanu, A.; Cristina, R.-T.; Skalicka-Woźniak, K.; Granica, S.; Czerwińska, M.E.; Kruk, A.; et al. Apiaceae Essential Oils: Boosters of Terbinafine Activity against Dermatophytes and Potent Anti-Inflammatory Effectors. Plants 2021, 10, 2378. [CrossRef]

95. Navarro-Rocha, J.; Andrés, M.F.; Díaz, C.E.; Burillo, J.; González-Coloma, A. Composition and biocidal properties of essential oil from pre-domesticated Spanish Satureja montana. Ind. Crops Prod. 2020, 145, 111958. [CrossRef]

96. Grochowski, D.M.; Uysal, S.; Aktumsek, A.; Granica, S.; Zengin, G.; Ceylan, R.; Locatelli, M.; Tomczyk, M. In vitro enzyme inhibitory properties, antioxidant activities, and phytochemical profile of Potentilla thuringiaca. Phytochem. Lett. 2017, 20, 365-372. [CrossRef]

97. Uysal, S.; Zengin, G.; Locatelli, M.; Bahadori, M.B.; Mocan, A.; Bellagamba, G.; de Luca, E.; Mollica, A.; Aktumsek, A. Cytotoxic and enzyme inhibitory potential of two Potentilla species (P. speciosa L. and P. reptans Willd.) and their chemical composition. Front. Pharmacol. 2017, 8, 290. [CrossRef] 